\title{
wiiw
}

\section{DECEMBER 2019}

\section{Working Paper 172}

\section{Public and Private Pension Systems and Macroeconomic Volatility in OECD Countries}

Mario Holzner, Stefan Jestl and David Pichler

The Vienna Institute for International Economic Studies Wiener Institut für Internationale Wirtschaftsvergleiche 



\title{
Public and Private Pension Systems and Macroeconomic Volatility in OECD Countries
}

\author{
MARIO HOLZNER \\ STEFAN JESTL \\ DAVID PICHLER
}

Mario Holzner is Executive Director at The Vienna Institute for International Economic Studies (wiiw). Stefan Jestl and David Pichler are Economists at wiiw. 



\section{Abstract}

This paper analyses the impact of public pension expenditures and pension funds' assets as well as their benefits on economic volatility. To do so, we use panel data for 35 OECD countries for the period 1980-2018 and apply a set of state-of-the-art econometric estimators. Our results show weak evidence of a negative impact of public pension expenditures as well as weak evidence of a positive impact of pension funds' benefits on volatility. Results were, however, found not to be very robust. In contrast, pension funds' assets do not show any evidence of being associated with economic volatility. Unsystematic fiscal policy, banking crises and political (in)stability, however, are revealed to be somewhat more robust determinants of economic volatility.

Keywords: Public pensions, private pensions, pension system, macroeconomic volatility, OECD

JEL classification: H55, J32, E24, E32 



\section{CONTENTS}

1. Introduction ........................................................................................................................................

2. Literature review ............................................................................................................................................ 3

3. Methodology \& Data.................................................................................................................. 6

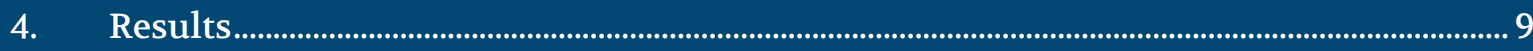

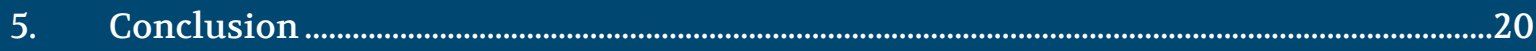

List of references .......................................................................................................................................................21

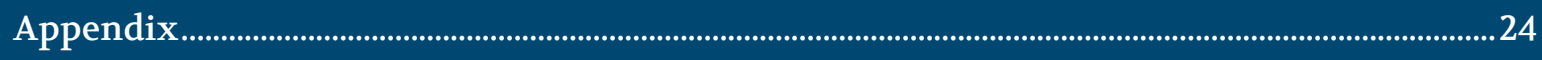




\section{TABLES AND FIGURES}

Table 1 / Baseline Regression - Real GDP p.c. Growth Rate Volatility............................................ 11

Table 2 / GMM Regressions - Real GDP p.c. Growth Rate Volatility .......................................... 13

Table 3 / Pension Funds' Assets - Real GDP p.c. Growth Rate Volatility ....................................... 15

Table 4 / GMM Regressions - Pension Funds' Assets - Real GDP p.c. Growth Rate Volatility ............ 16

Table 5 / Pension Funds' Benefits - Real GDP p.c. Growth Rate Volatility ..................................... 17

Table 6 / GMM Regressions - Pension Funds' Benefits - Real GDP p.c. Growth Rate Volatility .......... 18

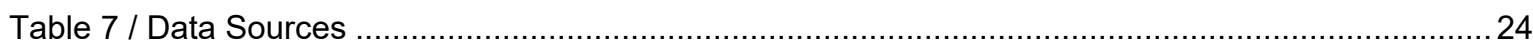

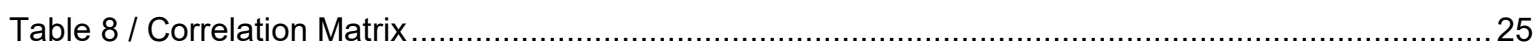

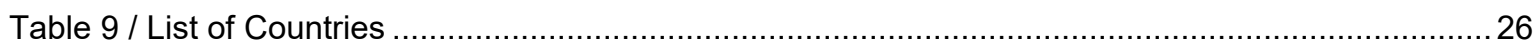

Table 10 / Baseline Regression - Gross Fixed Capital Formation Growth Rate Volatility......................27

Table 11 / Baseline Regression - Private Final Consumption Expenditure Growth Rate Volatility .........28

Table 12 / GMM Regressions - Gross Fixed Capital Formation Growth Rate Volatility ........................29

Table 13 / GMM Regressions - Private Final Consumption Expenditure Growth Rate Volatility ............30

Table 14 / Pension Funds' Assets - Gross Fixed Capital Formation Growth Rate Volatility ...................31

Table 15 / Pension Funds' Assets - Private Final Consumption Expenditure Growth Rate Volatility...... 32

Table 16 / GMM Regressions - Pension Funds' Assets - Gross Fixed Capital Formation Growth

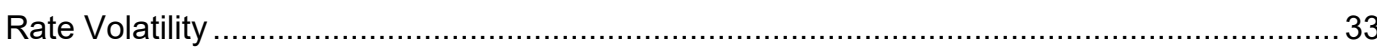

Table 17 / GMM Regressions - Pension Funds' Assets - Private Final Consumption Expenditure

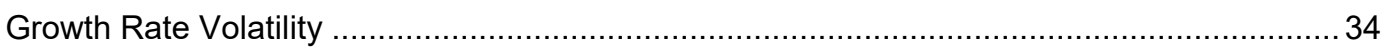

Table 18 / Pension Funds' Benefits- Gross Fixed Capital Formation Growth Rate Volatility ..................35

Table 19 / Pension Funds' Benefits - Private Final Consumption Expenditure Growth Rate Volatility ... 36

Table 20 / GMM Regressions - Pension Funds' Benefits - Gross Fixed Capital Formation Growth

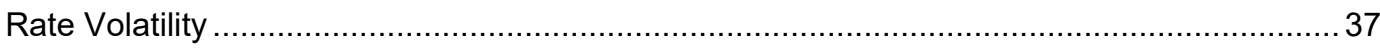

Table 21 / GMM Regressions - Pension Funds' Benefits- Private Final Consumption Expenditure

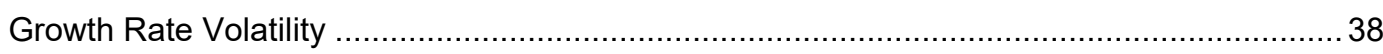

Figure 1 / Public Pension Expenditures and Real GDP p.c. Growth Volatility - 1980-2015 .................. 9 Figure 2 / Public Pension Expenditures and Gross Fixed Capital Formation \& Private Final Consumption Expenditures Growth Volatility - 1980-2015. 


\section{Introduction}

The debate about the choice of an appropriate pension system has been a faithful companion of many generations, ageing together with the societies of the western world. It has led to an economics of pensions (Barr and Diamond, 2006) which deals with a host of issues related to pension systems in general, such as the objectives of pension systems. From an individual point of view, pensions are a mechanism for consumption smoothing, and a means of insurance (e.g. see Lannoo et al., 2014). However, due to a number of market failures, voluntary pension arrangements are not sufficient and the public has a reason to act. Additional public objectives in this respect are poverty relief and redistribution. Pension systems are either organised as pay-as-you-go (PAYG, where pensions are paid out of current income), fully-funded (pensions are paid out of a fund built over years from members' contributions) or partially-funded pensions. The relation between contributions and benefits is a separate question. There are defined-contribution (DC) schemes with funded individual accounts and with varying real rates of return to pension assets. In the DC framework, one can choose between different pay-out profiles, such as lifelong annuities, a one-time capital pay-out at retirement or a pay-out in instalments over a fixed period (e.g. ten years). There are also defined-benefit (DB) schemes where a worker's pension is based on his wage history and represents a lifelong income stream where benefits do not necessarily have a direct link with the amount contributed. Public earnings-related pension schemes are basically of a DB nature and are PAYG financed.

Private pension schemes can incorporate a DC and/or a DB plan. For example, the Netherlands and the United Kingdom had traditionally private DB schemes. However, the majority of private companies have stopped new enrolments into DB schemes. Instead, there has been a reorientation towards private DC schemes (see Lannoo et al., 2014). In Europe, private DC schemes play a major role in Denmark, Estonia, Poland, Slovakia and Sweden. Austria is an example of a very pronounced public DB scheme. Other countries have co-existing important private and public systems, such as Belgium for instance. Moreover, recently, so-called notional defined contribution (NDC) schemes have evolved (see e.g. Marin, 2013) which are similar to DC systems but are not fully funded and may be entirely PAYG. NDC schemes have been implemented, e.g. in Sweden, combined with a mandatory funded DC pension plan.

In addition to the consumption smoothing and insurance function for individuals, pension systems determine several macroeconomic outcomes. Most importantly, a pension system has redistributional effects and determines labour supply and financial market development (Barr and Diamond, 2007).

Countries have adopted different combinations of pension scheme elements, and therefore, the extent to which pension systems determine macroeconomic outcomes is likely to vary significantly. Almost all OECD countries have altered their pension systems in the last decades and demographic challenges and fiscal sustainability issues will continue to drive pension system reforms.

In recent years, two major trends in pension reforms can be observed across most OECD countries. Frist, a shift away from DB towards DC schemes and second, a focus on a multi-pillar architecture and hence an increased role for private pension funds and less dominance of PAYG public pensions 
(Ebbinghaus, 2014). To inform policy makers on potential unintended negative externalities, it is crucial to analyse the risks that are linked to DC private pension schemes.

For less developed countries, the creation of private pension schemes has often been considered as an effective tool to create a domestic institutional investor base and deepen financial markets. This in turn could relax borrowing constraints and remove other financial frictions, and therefore, channel savings more efficiently towards productive investments. At the same time, financial development can lead to more risk-taking by entrepreneurs and banks, facilitate over-leverage and increase dependency on speculative international investors who can rapidly withdraw capital during financial turmoil (Singh, 1996)

For developed economies, private pension funds contribute much less to further financial deepening. However, pension funds tend to be buy-and-hold investors and can therefore be an additional source of long-term investment funding (Della Croce, 2011). Whether pension funds can improve the efficiency of resource allocation, depends on many factors indeed such as the level of financial market development, investment strategies and managing costs (Barr and Diamond, 2006).

Large institutional investors such as pension funds can also be a potential source of financial risk. A stress test conducted by the European Insurance and Occupation Pensions Authority (EIOPA) concluded that some individual pension funds are vulnerable to financial market shocks but that financial distress of pension funds is unlikely to impair the overall functioning of the financial system. However, Beetsma and Vos (2016) highlighted that imposing similar risk-based solvency requirements on all financial players may align the behaviour of financial market actors and amplify large financial shocks.

While pension schemes generally promote consumption smoothing due to compulsory saving schemes, the private pension schemes could potentially amplify macroeconomic fluctuations. The recent financial crisis has reignited the debate on how to reduce the risk of economic volatility which can curb long-term growth prospects and exacerbate inequality (Laursen and Mahajan, 2005; Ramey and Ramey, 1995).

While the link between volatility and trade openness and financial integration has received considerable attention, there is no research that we know of that studies the link between different pension schemes and macroeconomic fluctuations. Therefore, this research aims at filling this gap. In this study, we estimate the impact of public and private pension schemes on volatility in GDP, consumption and investment using a panel of 35 OECD countries between 1980 and 2018.

The rest of the paper is organised as follows: Section 2 summarises existing literature on the macroeconomic link between pension schemes and macroeconomic variables and the causes and consequences of macroeconomic fluctuations. Section 3 describes the underlying data and our empirical research strategy. Results are presented in Section 4 and Section 5 concludes. 


\section{Literature review}

It is for obvious reasons that the financial industry is advocating the adoption of private funded DC pension schemes instead of traditional public PAYG pension systems, often using angled indices of pension sustainability and one-sided arguments in support of their claims (see e.g. Allianz, 2014; Mercer, 2014; Bräuninger, 2010). However, it was a seminal study of the World Bank (1994) that started a global discussion on the privatisation and marketisation of pension systems. The World Bank approach to pension reform was a shift to a multi-pillar system (Holzmann, 1998). Some of the main arguments for a move towards funded pension schemes were the allegedly unsuccessful reforms of unfunded pension schemes in the light of population ageing and the associated labour market distortions of PAYG systems as well as the hope that decentralised funded pension plans would contribute to economic growth via higher saving rates or at least to a more efficient use of existing capital. It is argued that a shift to a funded system causes high transition costs but that would be compensated for by even higher long-term benefits due to high rates of return of funded assets, while fluctuations in asset prices are seen as a minor problem (Feldstein, 1997).

It is also acknowledged that funded schemes do not transfer the pension burden over time, as opposed to frequent thinking, but that apart from stimulating savings and investment they secure pension liabilities and solve the distributional problem of the national output between the retired and the nonretired (Kuné, 2001). Moreover, while public systems should provide a basic pension for low earners, higher income earners' pension portfolios should favour riskier investments, which in turn foster innovation and growth (Boeri et al., 2006). In this context, pension fund assets may favour more efficient and innovative investment opportunities (see e.g. Davis, 1998) or may boost economic growth through improved corporate performance (see e.g. Coronado et al., 2003). Furthermore, pension funds may also dampen stock market volatility (see e.g. Thomas et al., 2014 and Bohl et al., 2009). Thomas et al. (2014) found evidence for a significant reduction in volatility of stocks due to investments in shares by pension funds by analysing panel data for 34 OECD countries. On the other hand, Shiller (2015) argued that one of the reasons for the build-up of e.g. the Millennium Bubble in the US (1982-2000) was the shift from DB plans to DC plans, with a stronger reliance on investment in stocks.

Interestingly, the World Bank pension reform approach came under harsh criticism from within the World Bank itself. In direct reference to the World Bank (1994) study, Orszag and Stiglitz (1999) exposed ten myths about social security systems. These comprise the macroeconomic myths that individual accounts raise national saving; rates of return are higher under individual accounts; declining rates of return on pay-as-you-go systems reflect fundamental problems; and that investment of public trust funds in equities has no macroeconomic effects. The micro-economic myths include that labour market incentives are better under individual accounts; defined benefit plans necessarily provide more of an incentive to retire early; and that competition ensures low administrative costs under individual accounts. Among the political economy myths are the assumptions that corrupt and inefficient governments provide a rationale for individual accounts; bailout politics are worse under public defined benefit plans; and that investment of public trust funds is always squandered and mismanaged. 
Supporters of the PAYG system stress that apart from demographic trends, unemployment and female labour force participation trends are equally important to unfunded state pension schemes. Improvements in the latter two might be sufficient to rescue existing state schemes (Boldrin et al., 1999). Moreover, even in a neoclassical overlapping generations' model, it can be shown that the PAYG system might have a positive effect on capital in reducing the displacement of 'productive savings' in capital by 'non-productive savings' in financial sector equity. This effect might be stronger than the wellknown negative crowding-out effect in displacing aggregate savings (Roberts, 2003). Apart from physical capital, PAYG systems might also have positive effects on human capital. For a small open economy, where public education funding is determined by popular vote, it can be shown that the PAYG system allows future retirees to partially internalise positive externalities of public education due to the positive effect of higher future labour productivity on their pension benefits (Kaganovich and Meier, 2012). Furthermore, in matured economies with a large services sector, it might be detrimental to reduce the PAYG pension scheme as the elderly consume more labour-intensive services making them vulnerable to rising costs of services due to higher wages. This can be caused by increased capital accumulation in which case a fully funded pension system would indeed increase savings (van Groezen et al., 2007).

Another strand of literature stresses the lessons of the global financial crisis for the design of national pension systems. Wide fluctuations in asset returns can be problematic for DC pension systems (Burtless, 2010). In general, the vulnerability to financial market crises should be more prominent in countries with predominant market-based coordination mechanisms (Wiß, 2011). Hence, there might be a higher vulnerability to financial market crises in liberal market economies with high equity exposure (Wiß, 2015). It is suggested that pension funds, the social partners and the state need to adapt investment strategies and strengthen supervisory mechanisms (Ebbinghaus and Wiß, 2011).

Equity investment in transition economies is even more volatile than in the saturated western economies and the private sector may not provide enough investment projects to efficiently absorb mandated pension savings. Hence, the PAYG system might be the only viable system to perform well in terms of risk and volatility of returns in the transition economies (Festic and Mencinger, 2009). Another option for these countries, which also have generally strong business cycles with substantial fluctuations in production and unemployment, is to manage the pension systems more actively by making the contributions to the compulsory funded pension depend on the cyclical stance of the economy and by letting individuals withdraw accumulated funds during severe cyclical downturns. This in turn might help to stabilise the business cycle and enhance fiscal resilience (Staehr, 2011). In this respect, it was further argued by Staehr (2011) that the linkages between funded pension systems and the presence of business cycle fluctuations have been largely ignored in the academic and policy oriented literature so far, in spite of its likely consequences as regards economic welfare.

Direct impacts of pension systems on economic growth have been mostly inconclusive up to now. In a panel generalised least squares (GLS) setting for 17 OECD countries over five-year period averages between 1981 and 2000, Davis (2004) found no statistically significant effect of pension fund assets in percent of GDP on GDP growth. Accordingly, Hu (2005) found an insignificant result regarding the effects of the share of pension fund assets in GDP on GDP growth for a panel of 29 OECD and emerging market economies (EMEs) over five-year period averages between 1981 and 2000. However, for the sub-sample of OECD economies, the coefficient was negative and for the EMEs it was positive. Including countries without pension fund assets into the growth regression yielded an overall significant and negative coefficient. In a joint article, Davis and $\mathrm{Hu}(2008)$ used a Cobb-Douglas production function 
explaining GDP per capita by pension fund assets in GDP as well as capital stock per capita as the sole control variable for 37 countries and an average of about 15 years for the period up to 2003. Using a dynamic ordinary least squares (DOLS) as well as a dynamic heterogeneous model estimator in various specifications always yielded positive and significant coefficients of the pension fund assets variable for the EMEs and for the OECD countries and the full sample in most cases too.

As opposed to Davis and $\mathrm{Hu}$ (2008), Zandberg and Spierdijk (2013) employed a much broader definition of pension fund assets for 54 countries during the period 2001 to 2010. Employing a bias-corrected least square dummy variable (LSDV) estimator with bootstrap standard errors, they found an insignificant coefficient of total pension fund assets to GDP growth in various specifications in a GDP per capita growth regression, also controlling for the rate of return of the pension fund assets. Finally, Cavallini et al. (2013) tried to re-estimate the Davis and $\mathrm{Hu}$ (2008) setting using the total pension fund assets definition of Zandberg and Spierdijk (2013) together with the more sophisticated Common Correlated Effects Mean Group (CCEMG) and Common Correlated Effects Pooled (CCEP) estimators (accounting for a multifactor error structure) for 12 OECD countries over the period 2001-2010. They found no evidence of a long-term relationship between pension fund assets and economic growth.

In an effort to mitigate the reverse causality issue Bijlsma, Bonekamp, van Ewijk and Haaijen (2018) analysed the the growth-pension system nexus at the industry level. They tested the hypothesis that a deepening of capital markets triggered by an expansion of pension assets reduces companies' external finance dependency for 34 OECD countries for the period 2001-2010. Employing a two-step system GMM estimator, they found a significant positive impact of pension assets on industry growth which was particularly strong for industries with high external dependence.

Focusing on business cycle volatility, a strand of the literature addresses the relationship between economic volatility and the age distribution within a society (for a theoretical model, see Lugauer, 2012). Lugauer and Redmond (2012) used standard panel methods and found a significant effect of the age distribution on the magnitude of the GDP business cycle fluctuations. An increase in the middle-aged (30-59 years of age) share of the working-age population was correlated with a decrease in the output volatility. This confirms the results of Jaimovich and Siu (2010) who provided evidence that the age composition of the labour force accounts for a part of the variation in the business cycle volatility. However, a recent article by Everaert and Vierke (2016) questioned the robustness of these results in a replication of the above-mentioned studies.

Thus, given the inconclusiveness of the empirical literature on the economic growth nexus of funded pension systems and given that there is a lack of literature on the analysis of pension systems and the fluctuation of GDP growth (Staehr, 2011), we focus on explaining economic volatility using pension expenditures and pension funds' assets. As far as we know this has not been empirically analysed before. Moreover, the recent crisis induced changes in several countries' pension systems (Égert, 2012) and the financial crisis related problem of wide fluctuations in asset returns of private pension systems (Burtless, 2010) make research on the present topic highly relevant for policy makers. 


\section{Methodology \& Data}

Based on the lack of research in this field, we derive the following research hypotheses:

\section{Hypothesis 1:}

"Public pension benefit pay-outs have the ability to smoothen GDP growth volatility as well as the volatility of private household consumption expenditure and gross fixed capital formation growth.'

\section{Hypothesis 2:}

'(Private) pension funds' disbursements reinforce GDP growth volatility as well as the volatility of private household consumption expenditure and gross fixed capital formation growth.'

To test these hypotheses, we follow the state-of-the-art in estimating macroeconomic volatility in our empirical strategy. Specifically, we follow the approach of Dabla-Norris and Srivisal (2013) and rely on a (dynamic) panel regression framework. In doing so, we split the panel data into five-year periods and estimate a specification in the following form:

$$
V_{i t}=\alpha V_{i t-1}+\gamma P_{i t}+\delta P F_{i t}+\beta X_{i t}+u_{t}+\mu_{i}+\varepsilon_{i t},
$$

where $\mathrm{V}$ denotes the logarithm of the macroeconomic volatility at time $t$ for country $i ; P_{i t}$ is the measure of public pension benefit payments, while $\mathrm{PF}_{\mathrm{it}}$ indicates either the pension funds' assets or benefits paid out by pension funds; $X_{i t}$ is a set of control variables; $u_{t}$ is the time-fixed effect; $\mu_{i}$ is the country-fixed effect; and $\varepsilon_{i t}$ is the remaining error term.

Similar to Denizer et al. (2002), macroeconomic volatility refers to both overall macroeconomic volatility (volatility in real per capita output growth) and sectoral volatility (volatility of real per capita final and private consumption and total investment growth). We measure volatility as the standard deviation of the quarterly growth rate of the relevant variable within the five-year period.

The explanatory variable $P_{i t}$ is the variable of main interest with respect to Hypothesis 1 and represents the public pension expenditures in \% of GDP. Here, we concentrate on the sum of cash benefits of old age pension programmes. The variable is used for the initial year of each five-year period to account for possible endogeneity. The main assumption is that public pension benefits are predominantly based on pay-as-you-go and defined benefit pension schemes. According to our research Hypothesis 1, we expect that public pension expenditures are negatively correlated with macroeconomic volatility.

Further covariates are introduced in the vector $\mathrm{X}_{\mathrm{it}}$. In order to control for economic size, we include the logarithm of the beginning-of-period GDP per capita. Dabla-Norris and Srivisal (2013) argued that smaller economies may specialise in particular industries, which can be linked to higher volatility. Since the pension system might be correlated with other characteristics of the public sector, we also include a 
control variable that captures the general features of the social safety net of an economy (i.e. other public social expenditures). A pronounced social safety net may influence the business cycle via automatic stabilisers resulting in lower volatility. For this variable, we also use the initial value. We add the average trade (exports and imports) in \% of GDP to take trade openness into account. We expect to find a higher volatility for economies that are more exposed to trade. Moreover, we include the average growth rate of the respective underlying dependent variable to control for the overall growth path; and the average net government balance in \% of GDP to proxy a public budget constraint. The average oldage-dependency ratio controls for demographic factors. We further include an index of political regime (Polity index) to account for the quality of institutions. In this respect, we hypothesise to find a negative effect on volatility. Dabla-Norris and Srivisal (2013) and Kpodar et al. (2019) found volatility-dampening effects for the corresponding indicator.

Following Rumler and Scharler (2011) as well as Dabla-Norris and Srivisal (2013), we incorporate two additional variables that capture real external shocks. First, we consider a banking crisis dummy derived from Laeven and Valencia (2012) to capture financial crises. Second, we introduce the logarithm of the standard deviation of total government expenditures in \% of GDP. Rumler and Scharler (2011) referred to Fatás and Mihov (2003) and included this variable to control for unsystematic fiscal policy.

Finally, we add the share of pension assets (in its broader definition which includes for example, apart from pension fund assets, pension insurance contracts, book reserves on balance sheets of sponsoring companies, banks' managed funds, investment companies' managed funds) in \% of GDP, as indicated by $\mathrm{PF}_{\mathrm{it}}$ in (1), in the initial year of each five-year period. Pension funds are broadly seen as important sources of long-term, domestic capital (see Pedraza et al., 2017). To take the effects on economic growth and eventually growth volatility into account, we add pension fund assets to our set of explanatory variables. Moreover, we use pension fund assets as a proxy for the design of the pension system. Pension funds are strongly related to defined-contribution (DC) schemes and even more importantly to private pension schemes in particular. Besides the funds' assets, we also introduce benefits ${ }^{1}$ paid by pension funds in \% of GDP into $\mathrm{PF}_{\text {it }}$. These benefits have their sources in occupational pension plans as well as personal pension plans. As addressing private pension plans alone is not possible due to limited data availability, we rely on this broader definition of benefits from funded pension plans. Contrary to public pension benefits, we hypothesise that a positive effect on volatility for disbursements of pension funds will be found. The two variables related to pension funds are of particular interest for testing Hypothesis 2. As data on pension funds' assets and its disbursements are only available from 1995 onwards, we can use these variables for a shorter timeperiod only.

To estimate Specification 1, we apply three different econometric estimators. First, we estimate a nondynamic specification (without $\mathrm{V}_{\mathrm{it-1}}$ ) in an ordinary least squares framework. As we apply five-year periods, we face a sample with a small $\mathrm{T}$. We therefore also employ a bias-corrected least squares dummy variable estimator (LSDV) as introduced by Kiviet (1995) to estimate a dynamic specification. For both estimators, we report heteroscedasticity-robust standard errors. In the long run it might also be the case that macroeconomic volatility affects the design of the pension system, which eventually results in reverse causality. A longer period of higher macroeconomic volatility can foster the desire to establish or maintain a public pension system. As already discussed, we use quasi-lagged values for the variables

1 The OECD also provides information on private pension expenditures. We however cannot use this information as data availability is rather scarce. 
of main interest to mitigate the endogeneity issue. Beyond that, we further take endogeneity explicitly into account and employ a two-step system GMM panel data estimator as a third estimator (Arellano and Bond, 1991; Arellano and Bover, 1995; Blundell and Bond, 1998). Initially, the system GMM estimator had been designed for situations with large $\mathrm{N}$ and small $\mathrm{T}$ panels. Even though we face a small $\mathrm{N}$ and a small T, it is useful to apply this estimator for purposes of comparison. For the system GMM estimator, we compute robust two-step standard errors as proposed by Windmeijer (2004).

To conduct our analysis, we draw on data from various sources. Most of the data used in our analysis stem from the OECD.Stat databases and the IMF World Economic Outlook Database.

The OECD statistics provide quarterly national accounts data on the seasonally adjusted real GDP, private final consumption expenditures as well as for gross fixed capital formation growth rates for the period 1980-2018 (growth rate compared to previous quarter - seasonally adjusted). These data are used to construct our macroeconomic volatility indicators ${ }^{2}$. Moreover, the OECD Social Expenditure Database (SOCX) includes internationally comparable statistics on public pension expenditures and other social expenditures. We further use data on real GDP per-capita, old-age-dependency ratio and pension funds' assets and its disbursements from the OECD database. Information on further covariates is used from the IMF World Economic Outlook Database which includes government expenditures and government balance and trade. In addition, Laeven and Valancia (2012) provide information on banking crises over time. Finally, the Polity index is taken from the Polity IV Project. ${ }^{3}$ We summarise all variables used in this analysis and the corresponding sources in Table 7 in the Appendix. In addition, we report the unconditional correlation between each of the variable pairs in Table 8.

Ultimately, given the data availability, we end with an unbalanced panel data set that consists of 35 OECD countries with up to eight observations per country (see Table 9 in the Appendix for an overview). 


\section{Results}

As data on public pension expenditures are available from 1980 onwards, we start by focusing on the first research hypothesis. To provide a first insight into the relationship between public pension expenditures and the macroeconomic volatility, we take a look at the simple correlation between the two variables of interest. Figure 1 shows that countries with higher public pension expenditures on average experience lower real GDP growth volatility. Interestingly, the highly developed European countries Germany, Austria, Italy and France in particular reveal high public pension expenditures and a low overall volatility.

Figure 1 / Public Pension Expenditures and Real GDP p.c. Growth Volatility - 1980-2015

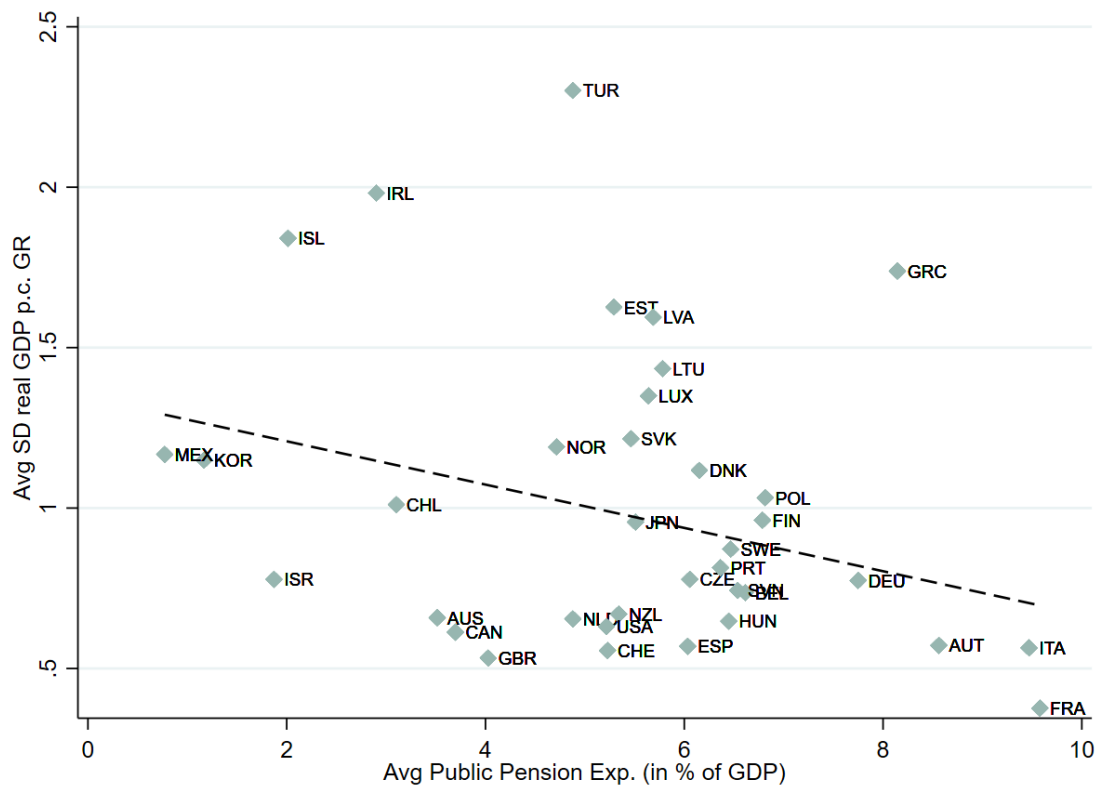

Source: OECD.

We further investigate the relationship with respect to sectoral volatility in Figure 2: (a) shows the partial correlation with volatility in gross fixed capital formation growth while (b) illustrates the relationship with volatility in private final consumption expenditures growth. As can be seen, we again find a negative correlation for both volatility measures. 
wiiw Working Paper 172

Figure 2 / Public Pension Expenditures and Gross Fixed Capital Formation \& Private Final Consumption Expenditures Growth Volatility - 1980-2015

(a) Gross fixed capital formation growth volatility

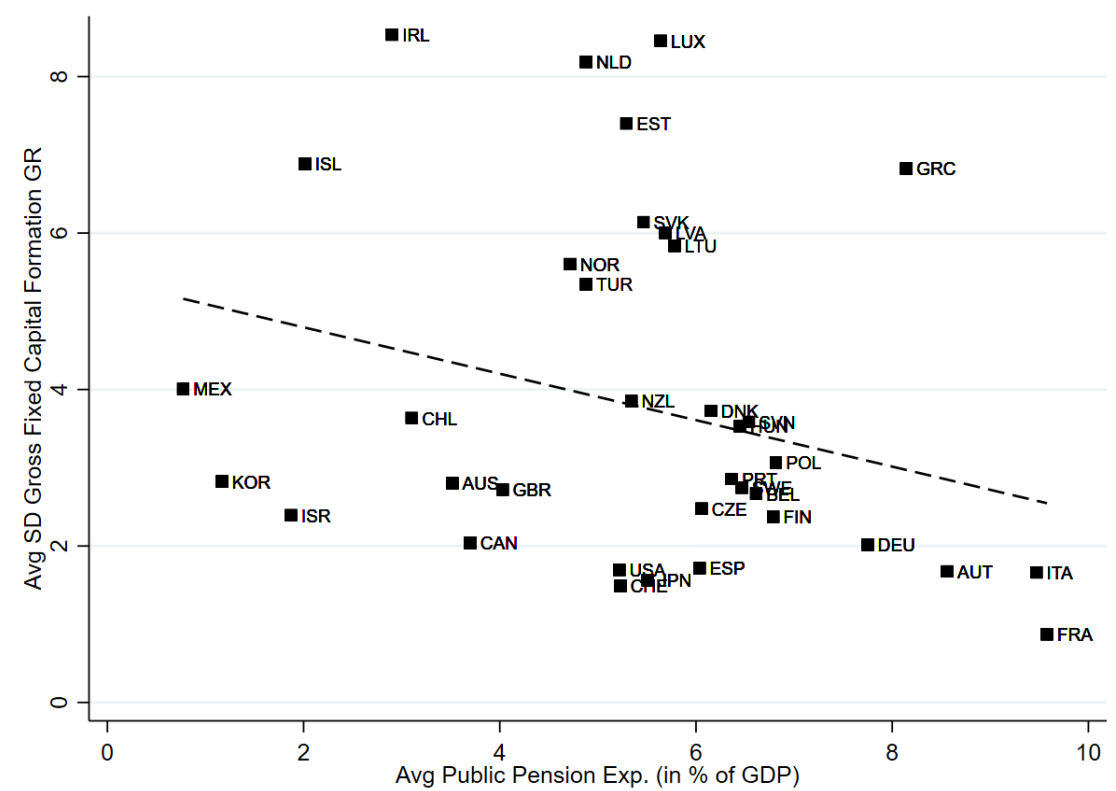

(b) Private final consumption expenditures growth volatility

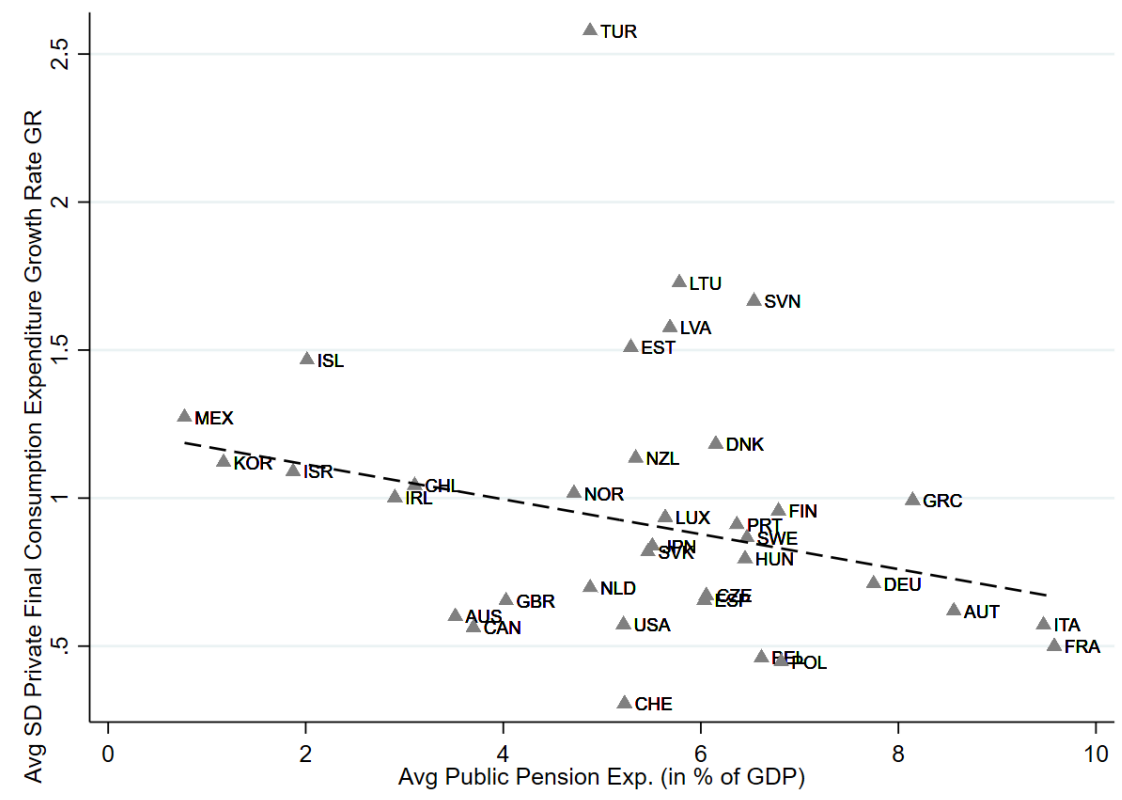

Source: OECD.

Accordingly, countries with higher public pension expenditures also tend to experience a lower sectoral volatility. Similar to Figure 1, the four highly developed European countries (DEU, AUT, ITA, FRA) again show both high public pension expenditures and a low volatility.

These simple bivariate correlations however ignore that there may be also other country-specific factors which have an impact on both public pension expenditures and economic volatility. For instance, as 
already discussed, the general level of economic development appears to have an impact on both variables. To take other factors into account too, we apply the econometric approach as discussed in Section 3. We therefore turn now to the results of our econometric analysis.

Table 1 reports the first set of our results which refer to the overall macroeconomic volatility. Columns (1) and (2) summarise the results of the simple panel regression using Least Squares Fixed Effects estimations, while Columns (3) and (4) list the results of the dynamic panel regression using BiasCorrected LSDV. Dabla-Norris and Srivisal (2013) and Rumler and Scharler (2011) use time-fixed effects in their specifications, whereas more recent studies, Kpodar and Imam (2016) and Kpodar et al. (2019) did not account for time-fixed effects when analysing growth volatility. Even though we find that most time dummies are not statistically significant, the F-test indicates that the time-fixed effects are mutually significantly different from zero. We therefore estimate both of our specifications with and without time-fixed effects.

Table 1 / Baseline Regression - Real GDP p.c. Growth Rate Volatility

\begin{tabular}{|c|c|c|c|c|}
\hline \multirow[t]{3}{*}{ Dependent variable: } & \multicolumn{4}{|c|}{ SD real GDP p.c. growth rate, log } \\
\hline & \multicolumn{2}{|c|}{ Least Squares Fixed Effects } & \multicolumn{2}{|c|}{ Bias-Corrected LSDV } \\
\hline & $(1)$ & $(2)$ & $(3)$ & $(4)$ \\
\hline \multirow[t]{2}{*}{ Lagged dependent variable } & - & - & 0.0692 & $0.222^{* * *}$ \\
\hline & $(-)$ & $(-)$ & $(0.081)$ & $(0.085)$ \\
\hline \multirow[t]{2}{*}{ Initial real GDP p.c. level, log } & $-1.032^{* \star *}$ & -0.821 & $-1.226^{\star * *}$ & $-0.726^{*}$ \\
\hline & $(0.241)$ & $(0.688)$ & $(0.337)$ & $(0.393)$ \\
\hline \multirow[t]{2}{*}{ Initial public pension exp., in \% of GDP } & $-0.0628^{\star \star *}$ & -0.0205 & $-0.0782^{*}$ & -0.00312 \\
\hline & $(0.022)$ & $(0.0250)$ & $(0.042)$ & $(0.038)$ \\
\hline \multirow[t]{2}{*}{ Old-age-dependency ratio } & -0.00372 & $0.0188^{*}$ & 0.0053 & 0.0117 \\
\hline & $(0.012)$ & $(0.010)$ & $(0.011)$ & $(0.010)$ \\
\hline \multirow[t]{2}{*}{ Real GDP p.c. growth rate } & -0.243 & -0.0519 & $-0.311^{* * *}$ & -0.0675 \\
\hline & $(0.146)$ & $(0.181)$ & $(0.100)$ & $(0.096)$ \\
\hline \multirow[t]{2}{*}{ Initial other social exp., in \% of GDP } & -0.0119 & -0.00465 & -0.0398 & -0.0395 \\
\hline & $(0.016)$ & $(0.018)$ & $(0.027)$ & $(0.026)$ \\
\hline \multirow[t]{2}{*}{ Trade openness } & -0.00122 & 0.000357 & -0.0001 & 0.000539 \\
\hline & $(0.002)$ & $(0.002)$ & $(0.003)$ & $(0.002)$ \\
\hline \multirow[t]{2}{*}{ Government balance } & -0.0185 & $-0.0389^{\star \star}$ & -0.00127 & -0.0231 \\
\hline & $(0.014)$ & $(0.015)$ & $(0.018)$ & $(0.017)$ \\
\hline \multirow[t]{2}{*}{ SD government expenditures } & $0.240^{* * *}$ & 0.0415 & $0.265^{\star * *}$ & 0.0651 \\
\hline & $(0.032)$ & $(0.041)$ & $(0.049)$ & $(0.056)$ \\
\hline \multirow[t]{2}{*}{ Banking crisis } & $0.188^{*}$ & 0.0714 & $0.249^{* *}$ & 0.0806 \\
\hline & $(0.107)$ & $(0.089)$ & $(0.104)$ & $(0.100)$ \\
\hline \multirow[t]{2}{*}{ Political stability } & $-0.0540^{* *}$ & $-0.0764^{\star * *}$ & -0.0347 & $-0.0869^{* *}$ \\
\hline & $(0.022)$ & $(0.028)$ & $(0.043)$ & $(0.040)$ \\
\hline Observations & 210 & 210 & 192 & 192 \\
\hline Number of countries & 35 & 35 & 35 & 35 \\
\hline Country-FE & $\mathrm{Y}$ & $\mathrm{Y}$ & $\mathrm{Y}$ & $\mathrm{Y}$ \\
\hline Year-FE & $\mathrm{N}$ & $\mathrm{Y}$ & $\mathrm{N}$ & $\mathrm{Y}$ \\
\hline
\end{tabular}

Note: Robust standard errors in parentheses; ${ }^{* * *} p<0.01,{ }^{* *} p<0.05,{ }^{*} p<0.1$; bias correction initialised by the Arellano-Bond estimator.

Source: OECD, IMF WEO, Polity IV Project. 
In a first step, we discuss the results of the additional explanatory variables. Overall, the estimated coefficients show the expected signs. The lagged dependent variable in the dynamic panel regression shows a positive estimated coefficient that is only statistically significant when we account for time-fixed effects. Thus, a higher macroeconomic volatility in preceding periods is on average associated with a higher current volatility. The economic size of a country enters with a robust negative sign, which is even more statistically significant in specifications without fixed effects. Accordingly, macroeconomic volatility tends to decrease as GDP per capita increases. In contrast, the old-age-dependency ratio and other social expenditures do not show any evidence of correlation with growth volatility. Interestingly, trade openness is also not associated with growth volatility. This is in line with the findings of Dabla-Norris and Srivisal (2013) who found no effect that emanated from trade openness when using a country sample that went beyond the OECD. The average real GDP p.c. growth rate seems to be only weakly correlated with volatility. Faster growing countries tend to experience a lower volatility. Likewise, a positive government balance reduces growth volatility on average. For our two shock variables - the standard deviation of total government expenditures and banking crisis - we also see the expected signs. Both variables show however statistically significant results only in the specifications without time-fixed effects. The higher the unsystematic fiscal policy in a country, the higher on average the growth volatility in this country will be. Similarly, a banking crisis tends to induce a higher macroeconomic volatility. We further find that stronger political institutions are associated with lower growth volatility.

After having discussed the results of our control variables, we now move on to the results of the variable of main interest. Given that we control for our set of explanatory variables and other time-invariant country-specific factors, we investigate the impact of public pension expenditures on overall macroeconomic volatility. The estimated coefficients show a consistently negative sign even though the results are only statistically different from zero when we do not use time-fixed effects. In principle, these results are in line with the findings in our descriptive analysis and suggest that higher public pension expenditures tend to reduce overall macroeconomic volatility.

So far, we have not explicitly accounted for endogeneity in our econometric procedure. As we apply initial values for the variable of main interest and control additionally for time-invariant country-specific factors, we reduce the risk of a bias in our results. Nevertheless, endogeneity may still be an issue. To address endogeneity explicitly, we employ a two-step system GMM estimator that utilises lagged variables (differences and levels) out of the set of used variables as instruments. Table 2 reports the results of the system two-step GMM regressions again using both a simple panel specification (Columns (1)-(2)) and a dynamic panel specification (Columns (3)-(4)). We again also estimate both specifications with and without time-fixed effects. To test the validity of the internal instruments, we calculate the Hansen-test to test for over-identifying restrictions and the Arellano-Bond-test to test for second-order serial correlation. As indicated in the last two rows in Table 2, both tests confirm the validity of the instruments.

As compared to the results in Table 1, we find a lower number of statistically significant estimated coefficients. In line with our previous findings, our shock variable, i.e. the standard deviation of total government expenditures, shows a positive impact on growth volatility. Moreover, strong political institutions reduce growth volatility on average. Interestingly, contrary to Table 1, trade openness now shows a weak positive impact on overall macroeconomic volatility. Most importantly, public pension expenditures show negative estimated coefficients in all four specifications. However, the results are 
only significantly different from zero at higher significance levels. Accordingly, as compared to the results of Table 1, pension expenditures exhibit only a weak negative impact on volatility.

\section{Table 2 / GMM Regressions - Real GDP p.c. Growth Rate Volatility}

\begin{tabular}{|c|c|c|c|c|}
\hline \multirow[t]{2}{*}{ Dependent variable: } & \multicolumn{4}{|c|}{$\begin{array}{c}\text { System GMM Two-Step } \\
\text { SD real GDP p.c. growth rate, log }\end{array}$} \\
\hline & (1) & (2) & (3) & (4) \\
\hline \multirow[t]{2}{*}{ Lagged dependent variable } & - & - & 0.0658 & 0.197 \\
\hline & $(-)$ & $(-)$ & $(0.106)$ & $(0.187)$ \\
\hline \multirow[t]{2}{*}{ Initial real GDP p.c. level, log } & 0.172 & -0.161 & 0.0725 & 0.132 \\
\hline & $(0.157)$ & $(0.489)$ & $(0.151)$ & $(0.547)$ \\
\hline \multirow[t]{2}{*}{ Initial public pension exp., in $\%$ of GDP } & -0.0866 & -0.0362 & $-0.111^{*}$ & -0.0186 \\
\hline & $(0.0591)$ & $(0.0628)$ & $(0.0616)$ & $(0.0667)$ \\
\hline \multirow[t]{2}{*}{ Old-age-dependency ratio } & -0.0142 & 0.0303 & 0.00839 & 0.0334 \\
\hline & $(0.0299)$ & $(0.0404)$ & $(0.0309)$ & $(0.0328)$ \\
\hline \multirow[t]{2}{*}{ Real GDP p.c. growth rate } & 0.0896 & -0.0353 & 0.130 & 0.142 \\
\hline & $(0.186)$ & $(0.259)$ & $(0.217)$ & $(0.268)$ \\
\hline \multirow[t]{2}{*}{ Initial other social exp., in \% of GDP } & -0.0226 & -0.0362 & -0.0210 & -0.0405 \\
\hline & $(0.0451)$ & $(0.0515)$ & $(0.0517)$ & $(0.0520)$ \\
\hline \multirow[t]{2}{*}{ Trade openness } & -0.000585 & $0.00437^{* *}$ & 0.000540 & $0.00446^{*}$ \\
\hline & $(0.00230)$ & $(0.00218)$ & $(0.00191)$ & $(0.00230)$ \\
\hline \multirow[t]{2}{*}{ Government balance } & -0.0203 & -0.0648 & -0.0367 & $-0.0576^{*}$ \\
\hline & $(0.0266)$ & $(0.0473)$ & $(0.0300)$ & $(0.0305)$ \\
\hline \multirow[t]{2}{*}{ SD government expenditures } & $0.399^{\star * *}$ & 0.0802 & $0.429^{\star * \star}$ & 0.109 \\
\hline & $(0.0637)$ & $(0.0615)$ & $(0.0558)$ & $(0.0984)$ \\
\hline \multirow[t]{2}{*}{ Banking crisis } & 0.0758 & 0.0288 & 0.102 & -0.140 \\
\hline & $(0.239)$ & $(0.323)$ & $(0.216)$ & $(0.313)$ \\
\hline \multirow[t]{2}{*}{ Political stability } & $-0.0667^{* *}$ & $-0.135^{\star \star *}$ & $-0.0854^{\star *}$ & $-0.0895^{\star * *}$ \\
\hline & $(0.0281)$ & $(0.0435)$ & $(0.0418)$ & $(0.0263)$ \\
\hline Observations & 210 & 210 & 192 & 192 \\
\hline Number of countries & 35 & 35 & 35 & 35 \\
\hline Country-FE & $\mathrm{Y}$ & $\mathrm{Y}$ & $\mathrm{Y}$ & $\mathrm{Y}$ \\
\hline Year-FE & $\mathrm{N}$ & Y & $N$ & Y \\
\hline Hansen test ( $p$-value) & 0.381 & 0.737 & 0.698 & 0.778 \\
\hline A-B AR(2) test ( $p$-value) & 0.794 & 0.637 & 0.576 & 0.889 \\
\hline
\end{tabular}

Note: Standard errors in parentheses are computed following Windmeijer (2004); A-B AR(2) - the Arellano-Bond test for serial correlation of second order; ${ }^{* * *} p<0.01,{ }^{* *} p<0.05,{ }^{*} p<0.1$

Source: OECD, IMF WEO, Polity IV Project.

In a next step, we analyse determinants of the sectoral volatility. The results for both gross fixed capital formation growth volatility and private final consumption expenditure growth volatility can be found in the Appendix.

Table 10 in the Appendix summarises the results for the baseline regressions concerning gross capital formation growth volatility. The structure is the same as in Table 1. Overall, the estimated coefficients show a different pattern as compared to the overall macroeconomic volatility. Only a small set of variables is revealed to have an effect on gross capital formation growth volatility. Our proxy for the welfare state level - other social expenditures - shows a robust negative impact on volatility. Thus, higher social expenditures (others than public pension expenditures) smooth gross capital formation on 
average. Likewise, we find robust results for our two shock variables. Similar to the overall macroeconomic volatility, an unsystematic fiscal policy tends to push volatility in gross capital formation growth. Moreover, a banking crisis also increases volatility on average. We then turn to the results of the public pension expenditures. Contrary to Table 1, we observe a positive estimated coefficient which is however significantly different from zero in only one specification. This positive effect suggests that public pension expenditures push rather than mitigate volatility. In addition to the baseline regressions, we also estimate a system GMM estimator for the gross capital formation growth volatility. The results of the system GMM estimator in Table 12 in the Appendix are largely in line with those in Table 10 in the Appendix. We however do not find any significant results for public pension expenditures.

In Table 11 in the Appendix, we also report the baseline regression results for private final consumption expenditure growth volatility. Here, we again find only a small set of variables which reveal significant estimated coefficients. Similar to the overall macroeconomic volatility, the economic size of a country has a strong negative impact on volatility in private final consumption. The higher the real per-capita GDP in countries, the lower the consumption volatility will be on average. The most robust results however exhibit the average private final consumption growth rate. A higher growth rate tends to be associated with lower consumption volatility. In addition, we again find positive results for the shock variable, i.e. unsystematic fiscal policy, and a mitigating effect for political stability. Most importantly however is that we find only weak results for the public pension expenditures. Interestingly, the only significant estimated coefficient shows a positive sign. Interestingly, this result suggests that public pension expenditures do not smooth consumption but do on average increase consumption volatility. When we then turn to the results of the system GMM estimator for consumption volatility in Table 13 in the Appendix, we also do not see a clear pattern in the results for the public pension expenditures. In all four specifications, we observe insignificant results. In Column (1), where the result is the closest of being significant at a $10 \%$ significance level, we see a negative sign.

\subsection{PENSION FUNDS' ASSETS}

Up to now, we have solely focused on the public pension expenditures. As already discussed in Section 4 , we also consider pension funds as a further explanatory variable to address our second research hypothesis. Pension funds are closely connected with the existing pension systems in countries. Furthermore, it is commonly argued that pension funds are important sources of long-term, domestic capital (see Pedraza et al., 2017). Thus, pension funds' assets might be important determinants of growth volatility. As this variable is only available from 1995 onwards, we can only run the regressions for a shorter time period. Moreover, data on pension funds' assets for Belgium, Hungary and Norway are not available.

Table 3 presents the baseline regression results for the overall macroeconomic volatility where we consider pension funds' assets as an additional explanatory variable. The results largely coincide with the results found in Table 1. Significant results are found again for economic size, the two shock variables and political stability. In the last row, we find the results for the pension funds' assets. Interestingly, pension funds' assets appear to be irrelevant for overall growth volatility. In all four specifications, the estimated coefficient is not significantly different from zero. This result seems to be consistent with Pedraza et al. (2017) who argued that most funds' investments are concentrated in bank deposits and traditional government bonds which means less funding for development. Turning to public 
pension expenditures, we however find a robust negative impact on growth volatility that is statistically significant in all four specifications. These findings are however not supported by the system GMM estimates in Table 4. Although all estimated coefficients show a negative sign, only the estimates in Columns (3) and (4) are somewhat close to being significant at a $10 \%$ significance level. Nevertheless, in general, the results suggest a negative effect of public pension expenditures on overall macroeconomic volatility.

Table 3 / Pension Funds' Assets - Real GDP p.c. Growth Rate Volatility

\begin{tabular}{|c|c|c|c|c|}
\hline \multirow[t]{3}{*}{ Dependent variable: } & \multicolumn{4}{|c|}{ SD real GDP p.c. growth rate, log } \\
\hline & \multicolumn{2}{|c|}{ Least Squares Fixed Effects } & \multicolumn{2}{|c|}{ Bias-Corrected LSDV } \\
\hline & $(1)$ & (2) & (3) & (4) \\
\hline \multirow[t]{2}{*}{ Lagged dependent variable } & - & - & 0.113 & $0.298^{*}$ \\
\hline & $(-)$ & $(-)$ & $(0.127)$ & $(0.153)$ \\
\hline \multirow[t]{2}{*}{ Initial real GDP p.c. level, log } & $-1.718^{\star *}$ & -0.84 & $-1.387^{*}$ & -0.282 \\
\hline & $(0.732)$ & (1.436) & $(0.822)$ & (1.074) \\
\hline \multirow[t]{2}{*}{ Initial public pension exp., in \% of GDP } & $-0.394^{* * *}$ & $-0.265^{\star *}$ & $-0.385^{\star * *}$ & $-0.254^{* *}$ \\
\hline & $(0.131)$ & $(0.111)$ & $(0.101)$ & $(0.118)$ \\
\hline \multirow[t]{2}{*}{ Old-age-dependency ratio } & -0.0125 & 0.0142 & -0.0141 & 0.00257 \\
\hline & $(0.030)$ & $(0.038)$ & $(0.031)$ & $(0.033)$ \\
\hline \multirow[t]{2}{*}{ Real GDP p.c. growth rate } & 0.331 & 0.214 & 0.392 & 0.318 \\
\hline & $(0.375)$ & $(0.358)$ & $(0.254)$ & $(0.251)$ \\
\hline \multirow[t]{2}{*}{ Initial other social exp., in \% of GDP } & 0.0024 & 0.0578 & -0.0167 & 0.054 \\
\hline & $(0.078)$ & $(0.069)$ & $(0.065)$ & $(0.064)$ \\
\hline \multirow[t]{2}{*}{ Trade openness } & -0.000578 & 0.00399 & -0.00216 & 0.00199 \\
\hline & $(0.008)$ & $(0.008)$ & $(0.006)$ & $(0.006)$ \\
\hline \multirow[t]{2}{*}{ Government balance } & -0.00916 & -0.0164 & -0.00692 & -0.0246 \\
\hline & $(0.058)$ & $(0.063)$ & $(0.047)$ & $(0.048)$ \\
\hline \multirow[t]{2}{*}{ SD government expenditures } & $0.277^{\star \star *}$ & 0.127 & $0.302^{* \star *}$ & 0.169 \\
\hline & $(0.083)$ & $(0.103)$ & $(0.096)$ & $(0.112)$ \\
\hline \multirow[t]{2}{*}{ Banking crisis } & $0.900^{* * *}$ & 0.39 & $0.913^{* * *}$ & 0.325 \\
\hline & $(0.242)$ & $(0.285)$ & $(0.274)$ & $(0.376)$ \\
\hline \multirow[t]{2}{*}{ Political stability } & -0.0932 & -0.104 & $-0.0954^{* *}$ & $-0.105^{* *}$ \\
\hline & $(0.598)$ & $(0.840)$ & $(0.048)$ & $(0.047)$ \\
\hline \multirow[t]{2}{*}{ Pension funds' assets, in \% of GDP } & 0.00398 & 0.00659 & 0.0036 & 0.00695 \\
\hline & $(0.005)$ & $(0.005)$ & $(0.005)$ & $(0.006)$ \\
\hline Observations & 97 & 97 & 97 & 97 \\
\hline Number of countries & 32 & 32 & 32 & 32 \\
\hline Country-FE & $\mathrm{Y}$ & $\mathrm{Y}$ & $\mathrm{Y}$ & $\mathrm{Y}$ \\
\hline Year-FE & $\mathrm{N}$ & $\mathrm{Y}$ & $\mathrm{N}$ & $\mathrm{Y}$ \\
\hline
\end{tabular}

Note: Bootstrapped robust standard errors in parentheses; ${ }^{* *} p<0.01,{ }^{* *} p<0.05,{ }^{*} p<0.1$; bias correction initialised by the Arellano-Bond estimator.

Source: OECD, IMF WEO, Polity IV Project.

In Tables 14 and 15 in the Appendix, we present the baseline regression results with pension funds' assets added to the covariates for the sectoral volatility. Interestingly, for both gross capital formation and final private consumption, pension funds' assets seem to be irrelevant for growth volatility. In contrast, public pension expenditures show a negative effect on volatility that is statistically significant, however, only for final private consumption. Although we also find a clear pattern of negative estimated coefficients for gross capital formation growth volatility, none of these estimates is significantly different from zero. Contrary to the overall 
macroeconomic volatility, the findings of public pension expenditures for sectoral volatility are confirmed in the results of the system GMM estimator in Tables 16 and 17 in the Appendix. Accordingly, public pension expenditures tend to smooth consumption, but not gross capital formation.

Table 4 / GMM Regressions - Pension Funds' Assets - Real GDP p.c. Growth Rate Volatility

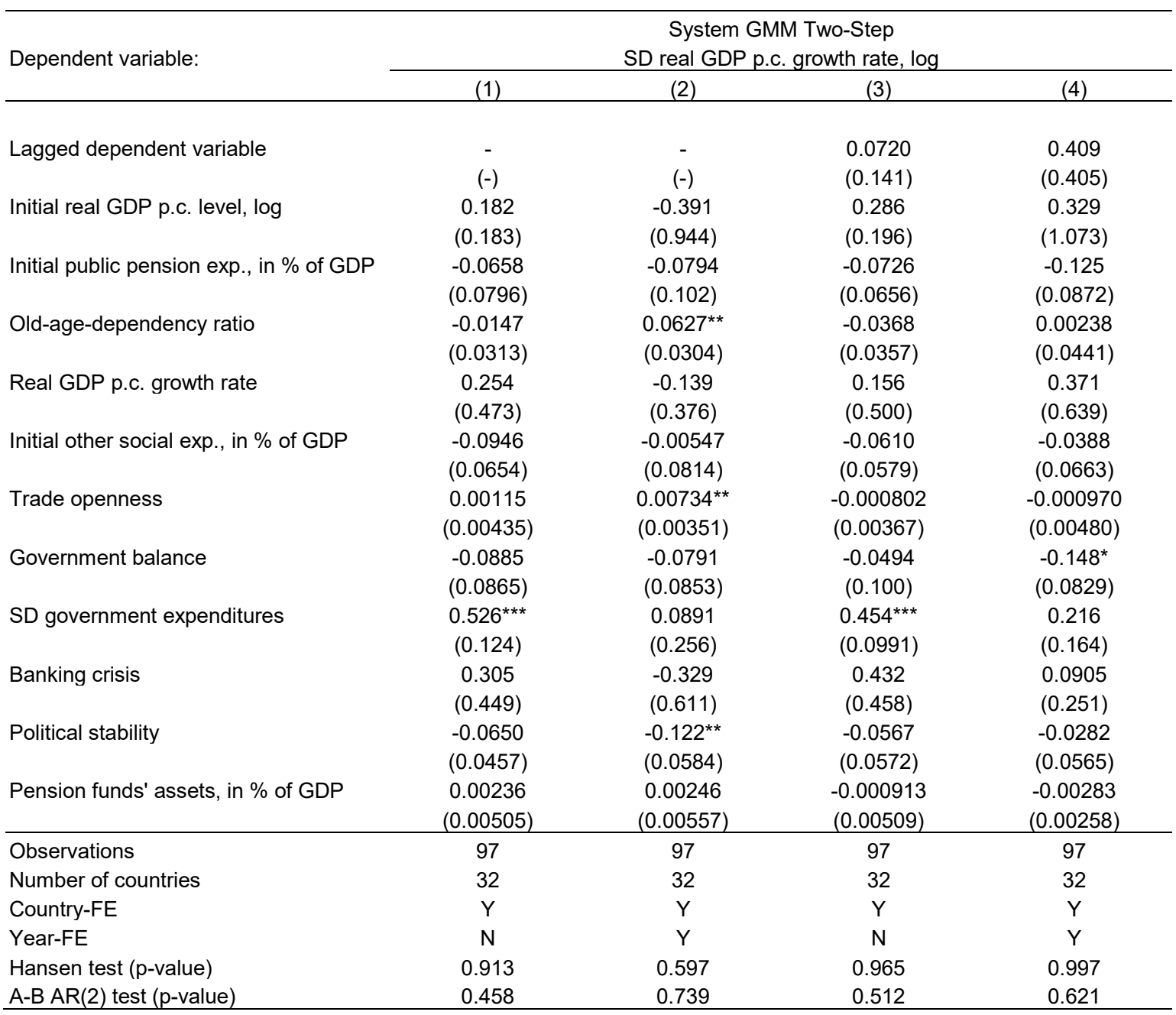

Note: Standard errors in parentheses are computed following Windmeijer (2004); A-B AR(2) - ArellanoBond test for serial correlation of second order; ${ }^{* * *} p<0.01,{ }^{* *} p<0.05,{ }^{*} p<0.1$.

Source: OECD, IMF WEO, Polity IV Project.

\subsection{PENSION FUNDS' BENEFITS}

Finally, we use benefits paid out by pension funds to address our second research hypothesis more directly. We have to stress again that benefits from funded pension plans come from occupational and personal pension plans. The data availability does not allow focusing on benefits from personal pension plans exclusively.

As pension funds' benefits are highly correlated with pension funds' assets, we cannot use both variables simultaneously in one specification. We therefore include pension funds' benefits instead of its 
assets in \% of GDP as an explanatory variable in the following. Similar to the regressions with pension funds' assets, we can only run the regression for a shorter period of time due to data availability. Furthermore, we lack information on pension funds' benefits in the following countries: Austria, Canada, Switzerland, Spain, Hungary, Ireland, Italy, Sweden and the USA.

Table 5 reports the first results for the specification with pension funds' benefits focusing on the overall macroeconomic volatility. In line with the results presented before, we find significant results for economic size and the shock variable standard deviation of total government expenditures. Moreover, there is also evidence that the average growth rate affects the overall volatility. More importantly, the estimates for the public pension expenditures in all four specifications show negative signs but are not statistically different from zero. The results in Columns (3) and (4) however tend to be somewhat significant at a $10 \%$ level. In addition, we find the results for the pension funds' benefits in the last row of Table 5. Interestingly, we observe positive estimated coefficients in all four specifications. Moreover, the result in Column (4) is statistically significant and the result in Column (2) is also close to being significant at least at a $10 \%$ level. These results partly suggest that benefits received from pension funds push the overall volatility on average.

\section{Table 5 / Pension Funds' Benefits - Real GDP p.c. Growth Rate Volatility}

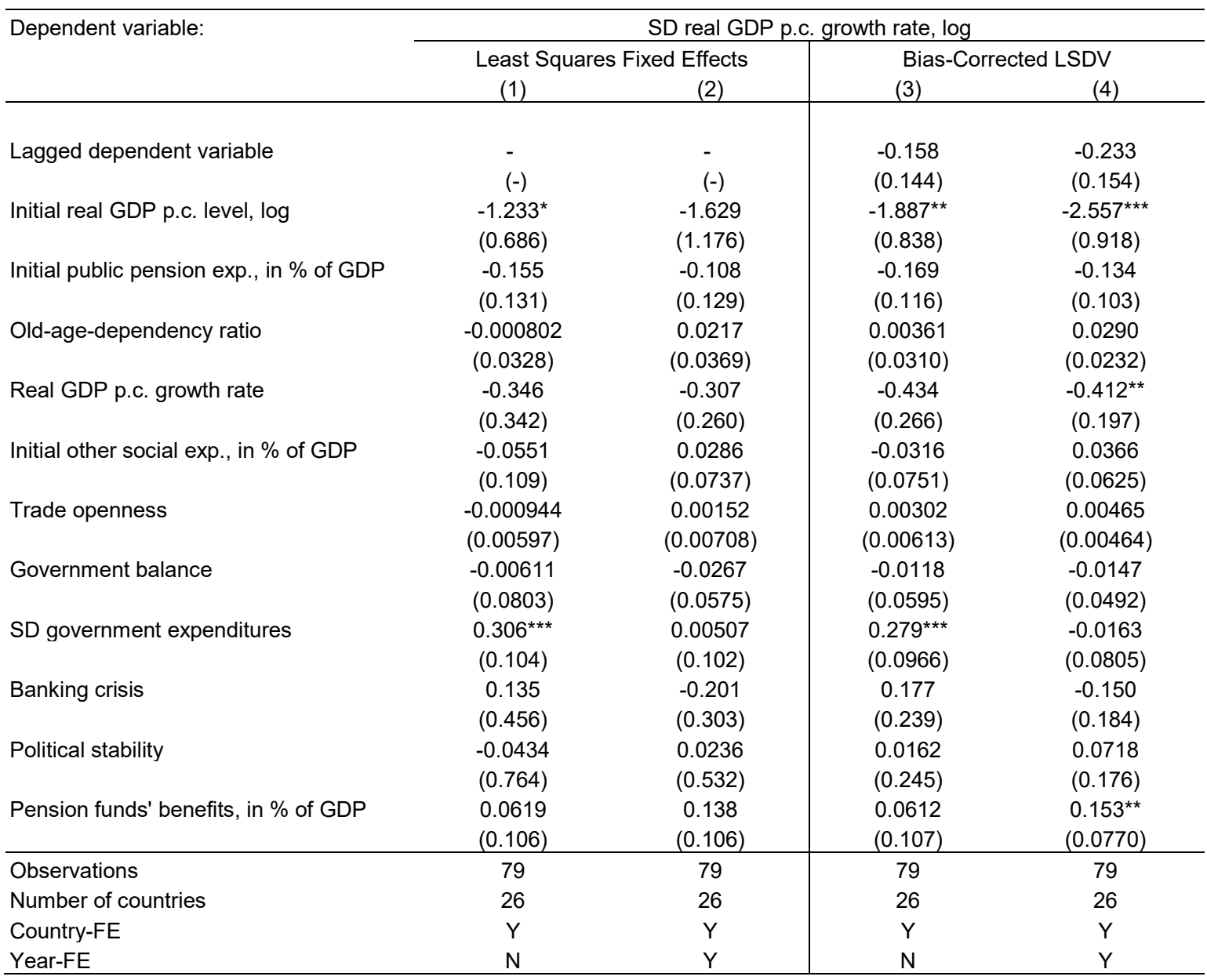

Note: Bootstrapped robust standard errors in parentheses; ${ }^{* *} p<0.01,{ }^{* *} p<0.05,{ }^{*} p<0.1$; bias correction initialised by the Arellano-Bond estimator.

Source: OECD, IMF WEO, Polity IV Project. 
These findings are supported to some extent by the results of the GMM regression found in Table 6. For public pension expenditures, we even find statistically significant results. In contrast, the results for pension funds' benefits are not significantly different from zero, even though the results in Columns (2) and (4) are at least close to being significant at a $10 \%$ level.

Table 6 / GMM Regressions - Pension Funds' Benefits - Real GDP p.c. Growth Rate Volatility

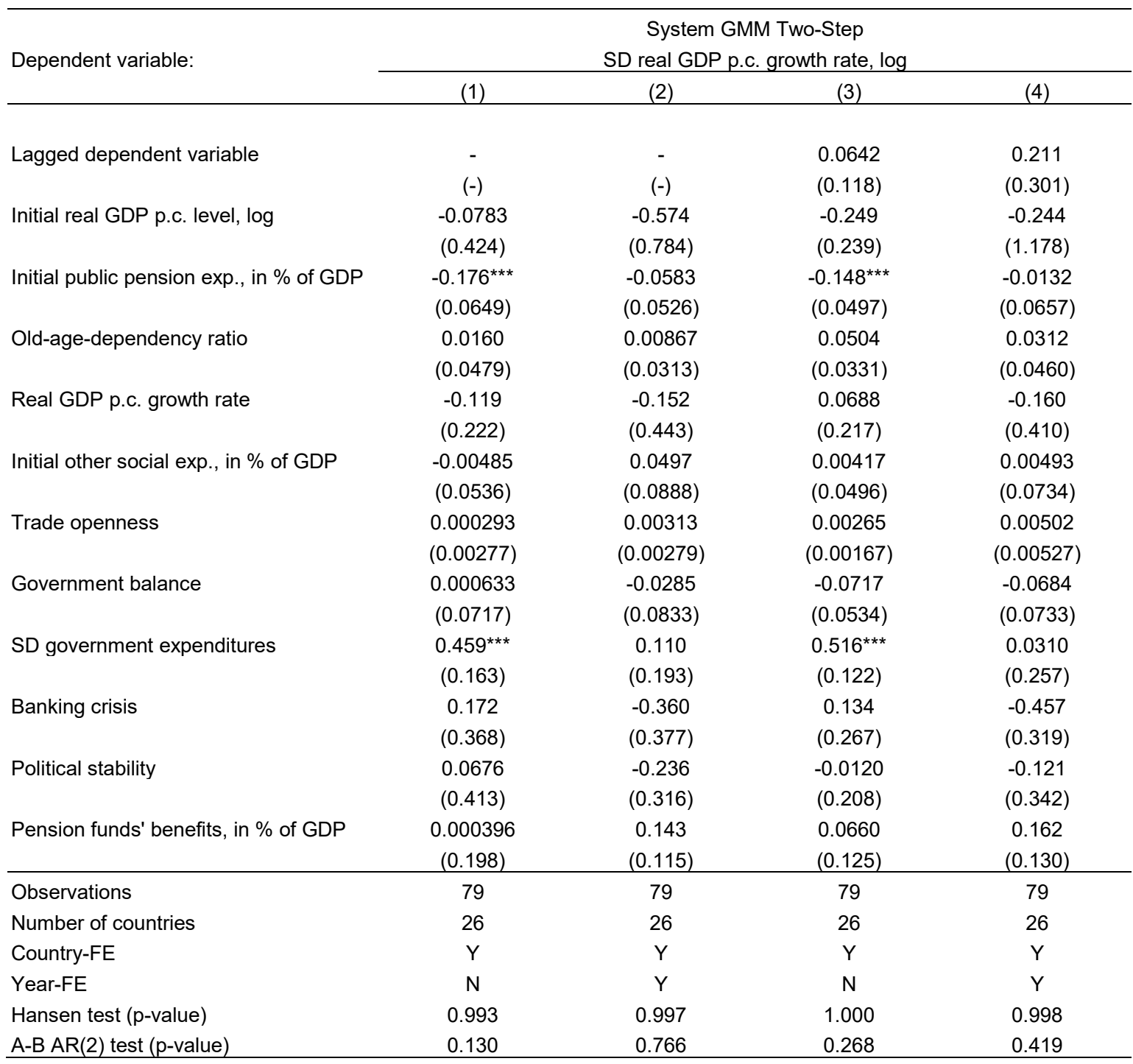

Note: Standard errors in parentheses are computed following Windmeijer (2004); A-B AR(2) - Arellano-Bond test for serial correlation of second order; ${ }^{* * *} p<0.01,{ }^{* *} p<0.05,{ }^{*} p<0.1$.

Source: OECD, IMF WEO, Polity IV Project.

Looking at the results for the sectoral volatility in Tables 18 and 19 in the Appendix, we find further interesting results. In line with previous findings, we do not find any evidence in Table 18 that public pension expenditures are associated with volatility in gross fixed capital formation growth. In contrast, pension funds' benefits appear to have a strong positive impact on volatility. We see statistically significant results in all four specifications. However, these findings are not confirmed in the results of the GMM regressions in Table 20 in the Appendix. Moving to the results for private final consumption, 
we observe a different pattern. None of the two variables of main interest shows a significant effect on consumption volatility, neither in the baseline specifications in Table 19 in the Appendix, nor in the GMM regression results in Table 21 in the Appendix.

\subsection{ADDITIONAL REGRESSIONS}

In addition to the regression results discussed above, we estimate further regression specifications. In the following, we discuss the results of regressions that incorporate non-linearities and results where we apply alternative measures for volatility.

\section{Non-Linear Effects}

In addition to the specification in (1), we also explore non-linearities in the effects of pension expenditures. In doing so, we test a squared term of the pension expenditures and interaction terms with the real GDP per capita level. This allows us to investigate whether the effect of pension expenditures on volatility depends on the expenditures' level and the economic size of a country. The results for GDP do not show any evidence for non-linear effects in pension expenditures. In line with the baseline findings, pension expenditures seem to be irrelevant for the volatility in gross fixed capital formation growth. However, we find an interesting result for the effect of public pension expenditures on volatility in private final consumption growth. Our results suggest that the impact of public pension expenditures depends on the GDP per capita level. Public pension expenditures smooth private consumption on average in countries with a lower GDP per capita: the negative effect becomes smaller in more economically developed countries.

\section{Alternative Volatility Measures}

To capture economic volatility, we apply the standard approach and calculate the standard deviation of the relevant variable within five-year periods. The literature on economic volatility proposes further approaches to measure volatility. Dabla-Norris and Srivisal (2013) and Rumler and Scharler (2011) applied the deviation of the respective growth rate from its Hodrick-Prescott (HP) filter trend to construct the dependent variables. We therefore re-estimate the specifications and consider the deviation of the relevant growth rates from its HP-filter trend for the dependent variable. The results for real GDP per capita, gross fixed-capital formation and private final consumption are consistent with those already presented in Section 4

Kpodar and Imam (2016) and Kpodar et al. (2019) introduced an alternative approach to measure economic volatility. Their approach relied on the assumption that the long-term component of the real GDP per capita follows an AR (1)-process with a time-trend. In this setting, volatility is calculated as the standard deviation of the residuals, which stem from country-specific estimations of the AR (1)-process. They argued that this approach is more flexible with respect to the functional form of the long-term component of the GDP series as compared to other approaches. We therefore also use this alternative approach to calculate volatility in the relevant variable. The results are largely in line with the estimates found using the other approaches. 


\section{Conclusion}

The question about an appropriate pension system is highly ranked in discussions in economics, politics and the general public. It is commonly argued that a stronger orientation towards funded pension and private pension systems can help countries to get relief from the financial pressure that arises due to demographic changes. Moreover, pension funds' assets are seen as an important source for economic development.

Research on the macroeconomic effects of pension systems so far has mostly focused on the effects of private pension fund assets on e.g. labour markets, financial markets or economic growth. There is no research that studies the link between different pension systems and macroeconomic volatility. In this study, we fill this gap and investigate the impact of pension expenditures on overall and sectoral economic volatility. In doing so, we use a panel of 35 OECD countries for the period 1980-2018 and employ three different econometric estimators, including a least squares fixed effect, a Bias-Corrected LSDV and a two-step system GMM estimator.

Although we find weak evidence of negative effects of public pension expenditures and weak evidence of positive effects of (private) pension funds' benefits on overall economic volatility, results were found not to be very robust. For sectoral volatility, including investment and consumption volatility, results do not show a clear pattern. In contrast, we do not find any evidence that pension funds' assets are associated with volatility. Our results however suggest that other factors such as the occurrence of a banking crisis, unsystematic fiscal policy and political (in)stability are to some extent more robust determinants of economic volatility.

Nevertheless, PAYG systems are still prevalent and therefore, private pension systems in most countries remain relatively small. If future pension reforms further strengthen the role of occupational and private pension schemes and hence lead to greater asset accumulation by pension funds, financial stability risks may rise and benefits retrieved from pension schemes could become more volatile. 


\section{List of references}

Arellano, M. and S. Bond (1991) Some Tests of Specification for Panel Data: Monte Carlo Evidence and an Application to Employment Equations. Review of Economic Studies, Vol. 58, No. 2, pp. 277-297.

Arellano, M. and O. Bover (1995) Another Look at the Instrumental Variable Estimation of Error-components Models. Journal of Econometrics, Vol. 68, No. 1, pp. 29-51.

Barr, N. and P. Diamond (2006) The economics of pensions. Oxford Review of Economic Policy, Vol. 22, No. 1, pp. 15-39.

Beetsma, R. and Siert, V. (2016, 02 23) Stabilisers or amplifiers: Pension funds as a source of systemic risk. Retrieved from https://voxeu.org/article/pension-funds-and-systemic-risk

Bijlsma, M., Bonekamp, J., van Ewijk, C., and Haaijen, F. (2018). Funded Pensions and Economic Growth. De Economist, Vol. 166, No. 3, pp. 337-362.

Blundell, R. and S. Bond (1998) Initial Conditions and Moment Restrictions in Dynamic Panel Data Model. Journal of Econometrics, Vol. 87, No. 1, pp. 115-143

Boeri, T., L. Bovenberg, B. Coeuré and A. Roberts (2006) Dealing with the New Giants: Rethinking the Role of Pension Funds. Geneva Reports on the World Economy, No. 8.

Bohl, M. T., J. Brzeszczynski and B. Wilfling (2009) Institutional investors and stock returns volatility: Empirical evidence from a natural experiment. Journal of Financial Stability, Vol. 5, No. 2, pp. 170-182.

Boldrin, M., J.J. Dolado, J.F. Jimeno, F. Peracchi, F. Breyer and R. Fernández (1999) The Future of Pensions in Europe. Economic Policy, Vol. 14, No. 29, pp. 287-320.

Bräuninger, D. (2010) Pensions in a post-crisis world: Fully-funded provision is vital. Deutsche Bank Research Current Issues, February 26.

Burtless, G. (2010) Lessons of the Financial Crisis for the Design of National Pension Systems. CESifo Economic Studies, Vol. 56, No. 3, pp. 323-349.

Cavallini, P., G. Carmeci and G. Millo (2013) Are funding of pensions and economic growth directly linked? New empirical results for some OECD countries. DEAMS Research Paper Series, No. 7.

Coronado, J. L., E. M. Engen and B. Knight (2003) Public funds and private capital markets: the investment practices and performance of state and local pension funds. National Tax Journal, Vol. 56, No. 3, pp. 579-594.

Dabla-Norris, E. and N. Srivisal (2013) Revisiting the Link Between Finance and Macroeconomic Volatility. IMF Working Paper, No. 13/29.

Davis, E.P. (1998) Pension funds: retirement-income security and capital markets: An international perspective. Oxford University Press.

Davis, E.P. (2004) Financial development, institutional investors and economic performance. In: Goodhart, C.A.E. (ed.) Financial Development and Economic Growth: Explaining the Links. Palgrave Macmillan, New York, pp. 149-182.

Davis, E.P. and Y.-W. Hu (2008) Does funding of pensions stimulate economic growth? Journal of Pension Economics and Finance, Vol. 7, No. 2, pp. 221-249.

Della Croce, R. (2011) Pension Funds Investment in Infrastructure: Policy Actions. OECD Working Papers on Finance, Insurance and Private Pensions No. 13. 
Denizer, C., M. Iyigun and A. Owen (2002) Finance and Macroeconomic Volatility. Contribution to Macroeconomics, Vol. 2, No. 1, Article 7.

Ebbinghaus, B. (2014) The Privatization and Marketization of Pensions in Europe: A Double Transformation Facing the Crisis. German Policy Studies. Special issue, forthcoming.

Ebbinghaus, B. and T. Wiß (2011) Taming pension fund capitalism in Europe: collective and state regulation in times of crisis. Transfer, Vol. 17, No. 1, pp. 15-28.

Égert, B. (2012) The Impact of Changes in Second Pension Pillars on Public Finances in Central and Eastern Europe. OECD Economics Department Working Papers, No. 942.

Everaert, G. and H. Vierke (2016) Demographics and Business Cycle Volatility: A Spurious Relationship? Journal of Applied Econometrics, forthcoming, version of record online: 31 March 2016.

Fatás, A., and I. Mihov (2003) The case for restricting fiscal policy discretion. The Quarterly Journal of Economics, Vol. 118, No. 4, pp. 1419-1447.

Feldstein, M. (1997) Transition to a Fully Funded Pension System: Five Economic Issues. NBER Working Paper, No. 6149.

Festic, M. and J. Mencinger (2009) The Perspective of Pension System Reforms in the New Member States. Prague Economic Papers, Vol. 18, No. 4, pp. 291-308.

Guger, A., K. Knittler, M. Marterbauer, M. Schratzenstaller and E. Walterskirchen (2008) Analyse alternativer Finanzierungsformen der sozialen Sicherungssysteme. WIFO report, June.

Holzmann, R. (1998) The World Bank Approach to Pension Reform. Social Protection Discussion Paper Series, No. 9807.

Hu, Y.-W. (2005) Pension Reform, Economic Growth and Financial Development - An Empirical Study. Brunel University Economics and Finance Working Papers, No. 0505.

Jaimovich, N. and H. E. Siu (2009) The young, the old, and the restless: Demographics and business cycle volatility. The American Economic Review, Vol. 99, No. 3, pp. 804-826.

Kaganovich, M. and V. Meier (2012) Social Security Systems, Human Capital, and Growth. Journal of Public Economic Theory, Vol. 14, No. 4, pp. 573-600.

Kiviet, J. (1995) On bias, inconsistency, and efficiency of various estimators in dynamic panel data models. Journal of Econometrics, Vol. 68, No. 1, pp. 53-78.

Kpodar, K., M. Le Goff and R. J. Singh (2019) Financial Deepening, Terms of Trade Shocks, and Growth Volatility in Low-Income Countries. IMF Working Paper, No. 19/68.

Kpodar, K., and P. Imam (2016) Does a Regional Trade Agreement Lessen or Worsen Growth Volatility? An Empirical Investigation. Review of International Economics, Vol. 24, No. 5, pp. 949-979.

Kuné, J.B. (2001) The Controversy of Funding Versus Pay-As-You-Go: What Remains of the Debate? The Geneva Papers on Risk and Insurance, Vol. 26, No.3, pp. 418-434.

Laeven, L. and F. Valencia (2012) Systemic Banking Crises Database: An Update. IMF Working Paper, No. $12 / 163$.

Lannoo, K., M. Barslund, A. Chmelar and M. von Werder (2014) Pension Schemes. European Parliament DG IPOL Study.

Lugauer, S. (2012) Demographic change and the great moderation in an overlapping generations model with matching frictions. Macroeconomic Dynamics, Vol. 16, No. 5, pp. 706-731.

Lugauer, S. and M. Redmond (2012) The age distribution and business cycle volatility: International evidence. Economics Letters, Vol. 117, No. 3, pp. 694-696. 
Marin, B. (2013) Welfare in an Idle Society? Reinventing Retirement, Work, Wealth, Health, and Welfare. Ashgate Publishing, Farnham.

Mercer (2014) Melbourne Mercer Global Pension Index, October.

Orszag, P.R. and J.E. Stiglitz (1999) Rethinking Pension Reform: Ten Myths About Social Security Systems. Paper presented at the World Bank conference on 'New Ideas About Old Age Security', Washington, D.C., September 14-15.

Pedraza, A., O. Fuentes, P. Searle, and F. Stewart (2017). Pension Funds and the Impact of Switching Regulation on Long-Term Investment. World Bank Policy Research Working Paper, No. 8143.

Ramey, G. and V. Ramey (1995) Cross-country Evidence on the Link between Volatility and Growth. American Economic Review, Vol. 85, No. 5, pp. 1138-1151.

Roberts, M.A. (2003) Can Pay-As-You-Go Pensions Raise the Capital Stock? The Manchester School, Supplement, pp. 1-20.

Rumler, F. and J. Scharler (2011) Labor Market Institutions and Macroeconomic Volatility in a Panel of OECD Countries. Scottish Journal of Political Economy, Vol. 58, No. 3, pp. 396-413.

Shiller, R. (2015) Irrational Exuberance. Princeton University Press.

Staehr, K. (2011) Funded Pension, Fiscal Strain and Stabilisation Policy in Central and Eastern Europe. In: Mooslechner, P. and D. Ritzberger-Grünwald (eds.) Limited Fiscal Space in CESEE: Needs and Options for Post-Crisis Reform. Proceedings of OeNB Workshops, No. 17, pp. 41-60.

Singh, A. (1996) Pension reform, the stock market, capital formation and economic growth: A critical commentary on the World Bank's proposals. International Social Security Review, Vol. 49, No. 3, pp. 21-43.

Thomas, A., L. Spataro and N. Mathew (2014) Pension funds and stock market volatility: An empirical analysis of OECD countries. Journal of Financial Stability. Vol. 11, No. C, pp. 92-103.

van Groezen, B., L. Meijdam and H.A.A. Verbon (2007) The Case for Pay-As-You-Go Pensions in a Service Economy. Scottish Journal of Political Economy, Vol. 54, No. 2, pp. 151-165.

Windmeijer, F. (2004) A Finite Sample Correction for the Variance of Linear Efficient Twostep GMM Estimators. Journal of Econometrics, Vol. 126, No. 1, pp. 25-51.

Wiß, T. (2011) Pension Fund Capitalism and Financial Crisis. IHS Political Science Series, No. 126.

Wiß, T. (2015) Pension fund vulnerability to the financial market crisis: The role of trade unions. European Journal of Industrial Relations, Vol. 21, No. 2, pp. 131-147.

World Bank (1994) Averting the Old Age Crisis: Policies to Protect the Old and Promote Growth. Oxford University Press.

Zandberg, E. and L. Spierdijk (2013) Funding of pensions and economic growth: are they really related? Journal of Pension Economics and Finance, Vol. 12, No. 2, pp. 151-167. 
Wiiw Working Paper 172

\section{Appendix}

\section{Table 7 / Data Sources}

\section{Variable}

Source

Quarterly real per capita GDP growth rate

Quarterly fixed capital formation growth rate

Quarterly private final consumption expenditures growth rate

Public pension expenditures (in \% of GDP)

Pension funds' assets (in \% of GDP)

OECD

Pension funds' benefits (in $\%$ of GDP)

Other social expenditures (in \% of GDP)

Real GDP per capita

Old-age-dependency ratio

Total government expenditures ( in \% of GDP)

Government balance (in \% of GDP)

IMF WEO

Trade (imports + exports) ratio (in \% of GDP)

Banking crisis dummy

Laeven \& Valencia (2012)

Polity index

Polity IV Project

Notes: Own illustration. 


\section{Table 8 / Correlation Matrix}

\begin{tabular}{|c|c|c|c|c|c|c|c|c|c|c|c|c|c|c|c|}
\hline Variable & $(1)$ & (2) & (3) & (4) & (5) & (6) & (7) & (8) & (9) & (10) & (11) & (12) & (13) & (14) & (15) \\
\hline SD real GDP p.c.GR, log & 1.000 & & & & & & & & & & & & & & \\
\hline SD gross fixed capital formation GR, log & 0.609 & 1.000 & & & & & & & & & & & & & \\
\hline SD private final consumption expenditure $G R$, log & 0.687 & 0.522 & 1.000 & & & & & & & & & & & & \\
\hline Initial public pension exp., in \% of GDP & -0.265 & -0.217 & -0.242 & 0.172 & 1.000 & & & & & & & & & & \\
\hline Old-age-dependency ratio & -0.071 & -0.053 & 0.027 & 0.043 & 0.098 & 1.000 & & & & & & & & & \\
\hline Real GDP p.c. GR & 0.087 & 0.162 & 0.058 & -0.311 & -0.284 & -0.129 & 1.000 & & & & & & & & \\
\hline Gross fixed capital formation GR & -0.029 & 0.204 & -0.056 & -0.096 & -0.113 & -0.003 & 0.791 & 1.000 & & & & & & & \\
\hline Initial other social exp., in \% of GDP & -0.253 & -0.146 & -0.265 & 0.515 & 0.487 & 0.149 & -0.198 & -0.025 & -0.267 & 1.000 & & & & & \\
\hline Trade openness & 0.131 & 0.431 & 0.018 & 0.329 & -0.007 & -0.236 & 0.163 & 0.232 & 0.027 & 0.202 & 1.000 & & & & \\
\hline Government balance & -0.072 & 0.104 & -0.012 & 0.306 & -0.141 & 0.035 & 0.246 & 0.247 & 0.303 & 0.039 & 0.174 & 1.000 & & & \\
\hline SD government expenditures & 0.479 & 0.360 & 0.403 & -0.085 & -0.038 & -0.111 & -0.125 & -0.154 & -0.133 & 0.115 & 0.055 & -0.192 & 1.000 & & \\
\hline Banking crisis & -0.001 & 0.104 & -0.038 & 0.237 & 0.235 & 0.159 & -0.241 & -0.071 & -0.305 & 0.212 & 0.249 & -0.123 & 0.023 & 1.000 & \\
\hline Political stability & -0.155 & -0.049 & -0.283 & 0.327 & 0.249 & -0.265 & -0.144 & -0.012 & -0.122 & 0.385 & 0.099 & 0.021 & 0.088 & -0.009 & 1.000 \\
\hline
\end{tabular}

Notes: Own illustration.

Source: OECD, IMF WEO, Polity IV Project. 
wiiw Working Paper 172

Table 9 / List of Countries

\begin{tabular}{cc}
\hline Country & \# of observations \\
\hline AUS & 6 \\
AUT & 6 \\
BEL & 8 \\
CAN & 8 \\
CHE & 7 \\
CHL & 5 \\
CZE & 5 \\
DEU & 5 \\
DNK & 8 \\
ESP & 8 \\
EST & 4 \\
FIN & 8 \\
FRA & 8 \\
GBR & 8 \\
GRC & 8 \\
HUN & 4 \\
IRL & 5 \\
ISR & 5 \\
ITA & 4 \\
JPN & 6 \\
KOR & 8 \\
LTU & 8 \\
LUX & 5 \\
LVA & 5 \\
MEX & 4 \\
NLD & 5 \\
NOR & 5 \\
NZL & 5 \\
POL & 5 \\
PRT & 5 \\
SVK & 5 \\
SVN & 5 \\
SWE & 5 \\
TUR & 5 \\
USA & 5 \\
\hline & 5 \\
\hline
\end{tabular}

Notes: Own illustration. 
Table 10 / Baseline Regression - Gross Fixed Capital Formation Growth Rate Volatility

\begin{tabular}{|c|c|c|c|c|}
\hline \multirow[t]{3}{*}{ Dependent variable: } & \multicolumn{4}{|c|}{ SD gross fixed capital formation growth rate, log } \\
\hline & \multicolumn{2}{|c|}{ Least Squares Fixed Effects } & \multicolumn{2}{|c|}{ Bias-Corrected LSDV } \\
\hline & $(1)$ & $(2)$ & $(3)$ & $(4)$ \\
\hline \multirow[t]{2}{*}{ Lagged dependent variable } & - & - & $0.165^{\star}$ & 0.125 \\
\hline & $(-)$ & $(-)$ & $(0.099)$ & $(0.092)$ \\
\hline \multirow[t]{2}{*}{ Initial real GDP p.c. level, log } & -0.295 & 0.38 & -0.204 & 0.505 \\
\hline & $(0.281)$ & $(0.468)$ & $(0.339)$ & $(0.438)$ \\
\hline \multirow[t]{2}{*}{ Initial public pension exp., in \% of GDP } & 0.0531 & 0.0953 & 0.0462 & $0.104^{* *}$ \\
\hline & $(0.062)$ & $(0.065)$ & $(0.044)$ & $(0.046)$ \\
\hline \multirow[t]{2}{*}{ Old-age-dependency ratio } & 0.000922 & 0.0106 & 0.00393 & 0.00906 \\
\hline & $(0.013)$ & $(0.013)$ & $(0.012)$ & $(0.012)$ \\
\hline \multirow[t]{2}{*}{ Gross fixed capital formation growth rate } & 0.0499 & 0.0769 & 0.0203 & 0.0507 \\
\hline & $(0.066)$ & $(0.070)$ & $(0.037)$ & $(0.038)$ \\
\hline \multirow[t]{2}{*}{ Initial other social exp., in \% of GDP } & $-0.0660^{* * *}$ & $-0.0482^{*}$ & $-0.0722^{\star * *}$ & $-0.0541^{*}$ \\
\hline & $(0.019)$ & $(0.024)$ & $(0.028)$ & $(0.030)$ \\
\hline \multirow[t]{2}{*}{ Trade openness } & 0.0011 & 0.00138 & 0.00137 & 0.00166 \\
\hline & $(0.003)$ & $(0.002)$ & $(0.003)$ & $(0.003)$ \\
\hline \multirow[t]{2}{*}{ Government balance } & -0.00482 & 0.00665 & 0.00192 & 0.0127 \\
\hline & $(0.021)$ & $(0.024)$ & $(0.019)$ & $(0.020)$ \\
\hline \multirow[t]{2}{*}{ SD government expenditures } & $0.236^{\star * *}$ & $0.127^{* *}$ & $0.246^{\star \star *}$ & $0.118^{*}$ \\
\hline & $(0.039)$ & $(0.047)$ & $(0.049)$ & $(0.064)$ \\
\hline \multirow[t]{2}{*}{ Banking crisis } & $0.285^{\star \star *}$ & $0.299^{* * *}$ & $0.239^{* *}$ & $0.237^{* *}$ \\
\hline & $(0.100)$ & $(0.095)$ & $(0.108)$ & $(0.120)$ \\
\hline \multirow[t]{2}{*}{ Political stability } & -0.0257 & -0.0134 & -0.0404 & -0.0346 \\
\hline & $(0.036)$ & $(0.028)$ & $(0.045)$ & $(0.047)$ \\
\hline Observations & 210 & 210 & 192 & 192 \\
\hline Number of countries & 35 & 35 & 35 & 35 \\
\hline Country-FE & $\mathrm{Y}$ & $\mathrm{Y}$ & $\mathrm{Y}$ & $\mathrm{Y}$ \\
\hline Year-FE & $\mathrm{N}$ & $\mathrm{Y}$ & $\mathrm{N}$ & $Y$ \\
\hline
\end{tabular}

Note: Robust standard errors in parentheses; ${ }^{* * *} p<0.01,{ }^{* *} p<0.05,{ }^{*} p<0.1$; bias correction initialised by the Arellano-Bond estimator.

Source: OECD, IMF WEO, Polity IV Project. 
Wiiw Working Paper 172

Table 11 / Baseline Regression - Private Final Consumption Expenditure Growth Rate Volatility

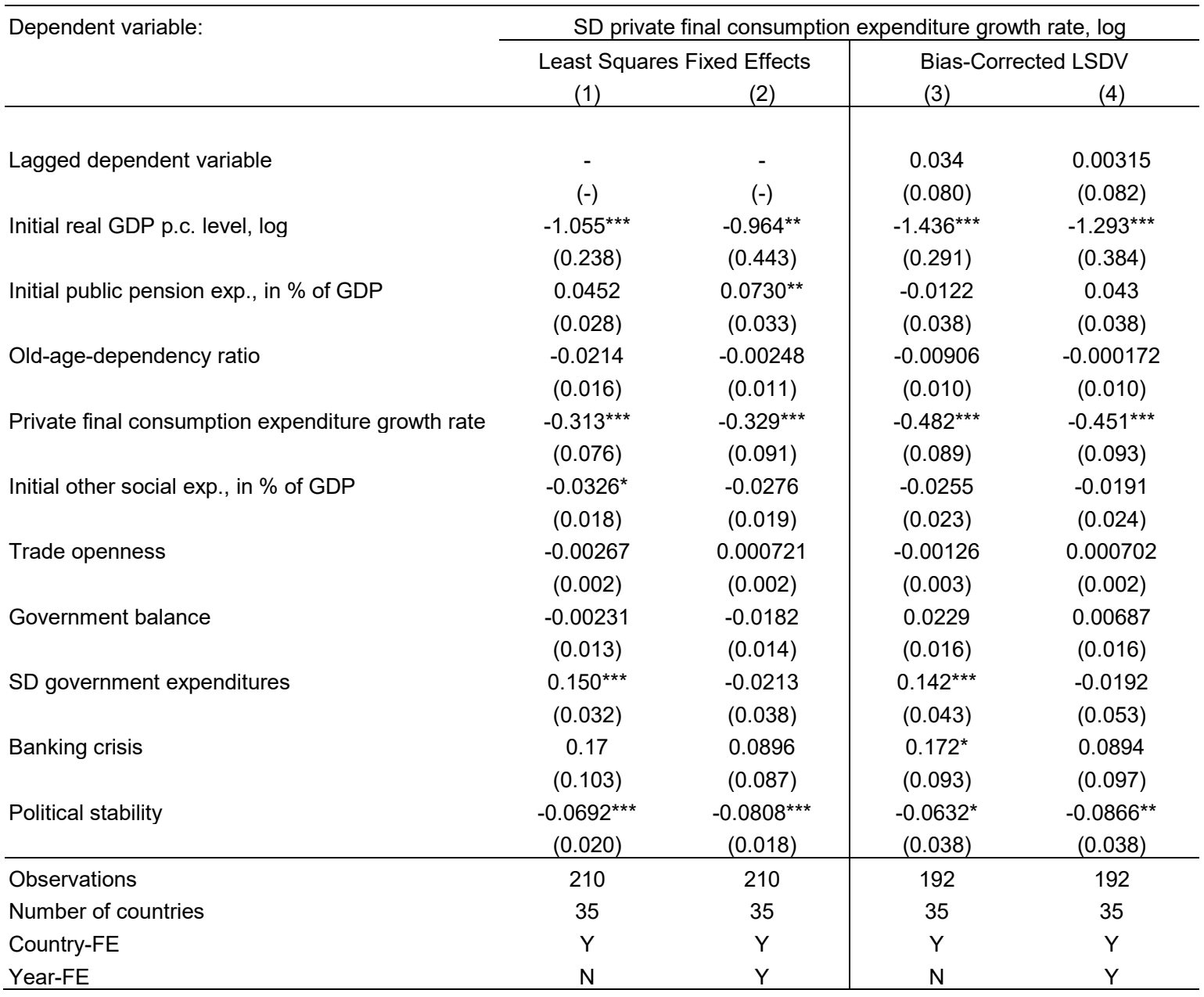

Note: Robust standard errors in parentheses; ${ }^{* *} p<0.01,{ }^{* *} p<0.05,{ }^{*} p<0.1$; bias correction initialised by the Arellano-Bond estimator.

Source: OECD, IMF WEO, Polity IV Project. 
Table 12 / GMM Regressions - Gross Fixed Capital Formation Growth Rate Volatility

\begin{tabular}{|c|c|c|c|c|}
\hline \multirow[t]{2}{*}{ Dependent variable: } & \multicolumn{4}{|c|}{$\begin{array}{c}\text { System GMM Two-Step } \\
\text { SD gross fixed capital formation growth rate, log }\end{array}$} \\
\hline & $(1)$ & $(2)$ & $(3)$ & $(4)$ \\
\hline \multirow[t]{2}{*}{ Lagged dependent variable } & - & - & 0.209 & $0.365^{\star \star *}$ \\
\hline & $(-)$ & $(-)$ & $(0.177)$ & $(0.137)$ \\
\hline \multirow[t]{2}{*}{ Initial real GDP p.c. level, log } & 0.0906 & -0.437 & 0.0820 & 0.118 \\
\hline & $(0.116)$ & $(0.926)$ & $(0.119)$ & $(0.443)$ \\
\hline \multirow[t]{2}{*}{ Initial public pension exp., in $\%$ of GDP } & -0.0428 & -0.0157 & 0.000527 & 0.0524 \\
\hline & $(0.0587)$ & $(0.0669)$ & $(0.0548)$ & $(0.0681)$ \\
\hline \multirow[t]{2}{*}{ Old-age-dependency ratio } & 0.0135 & -0.0348 & 0.0103 & -0.0184 \\
\hline & $(0.0206)$ & $(0.0597)$ & $(0.0233)$ & $(0.0502)$ \\
\hline \multirow[t]{2}{*}{ Gross fixed capital formation growth rate } & 0.0749 & -0.0254 & 0.0436 & -0.0329 \\
\hline & $(0.0556)$ & $(0.109)$ & $(0.0630)$ & $(0.0915)$ \\
\hline \multirow[t]{2}{*}{ Initial other social exp., in \% of GDP } & $-0.0474^{*}$ & 0.000704 & $-0.0677^{* \star *}$ & -0.0434 \\
\hline & $(0.0258)$ & $(0.0839)$ & $(0.0262)$ & $(0.0466)$ \\
\hline \multirow[t]{2}{*}{ Trade openness } & $0.00478^{* * *}$ & 0.00392 & $0.00407^{* *}$ & 0.00346 \\
\hline & $(0.00156)$ & $(0.00257)$ & $(0.00182)$ & $(0.00220)$ \\
\hline \multirow[t]{2}{*}{ Government balance } & -0.00592 & 0.0561 & 0.00134 & 0.0376 \\
\hline & $(0.0232)$ & $(0.0620)$ & $(0.0230)$ & $(0.0352)$ \\
\hline \multirow[t]{2}{*}{ SD government expenditures } & $0.269^{* * *}$ & $0.198^{*}$ & $0.280^{* \star *}$ & 0.0751 \\
\hline & $(0.0674)$ & $(0.103)$ & $(0.0667)$ & $(0.114)$ \\
\hline \multirow[t]{2}{*}{ Banking crisis } & 0.0690 & 0.368 & 0.0931 & 0.232 \\
\hline & $(0.142)$ & $(0.473)$ & $(0.139)$ & $(0.362)$ \\
\hline \multirow[t]{2}{*}{ Political stability } & -0.0302 & -0.00232 & -0.0201 & -0.00938 \\
\hline & $(0.0255)$ & $(0.0692)$ & $(0.0217)$ & $(0.0330)$ \\
\hline Observations & 210 & 210 & 192 & 192 \\
\hline Number of countries & 35 & 35 & 35 & 35 \\
\hline Country-FE & $\mathrm{Y}$ & $\mathrm{Y}$ & $\mathrm{Y}$ & $\mathrm{Y}$ \\
\hline Year-FE & $\mathrm{N}$ & Y & $\mathrm{N}$ & Y \\
\hline Hansen test ( $p$-value) & 0.754 & 0.798 & 0.968 & 0.954 \\
\hline A-B AR(2) test ( $p$-value) & 0.422 & 0.283 & 0.423 & 0.362 \\
\hline
\end{tabular}


Wiiw Working Paper 172

Table 13 / GMM Regressions - Private Final Consumption Expenditure Growth Rate Volatility

\begin{tabular}{|c|c|c|c|c|}
\hline \multirow[t]{2}{*}{ Dependent variable: } & \multicolumn{4}{|c|}{$\begin{array}{l}\text { System GMM Two-Step } \\
\text { SD private final consumption expenditure growth rate, log }\end{array}$} \\
\hline & $(1)$ & (2) & $(3)$ & $(4)$ \\
\hline \multirow[t]{2}{*}{ Lagged dependent variable } & - & - & $0.189^{* *}$ & 0.114 \\
\hline & $(-)$ & $(-)$ & $(0.0898)$ & $(0.171)$ \\
\hline \multirow[t]{2}{*}{ Initial real GDP p.c. level, log } & 0.175 & -0.644 & $0.252^{\star * *}$ & -0.465 \\
\hline & $(0.125)$ & $(0.878)$ & $(0.0870)$ & $(0.518)$ \\
\hline \multirow[t]{2}{*}{ Initial public pension exp., in $\%$ of GDP } & -0.0415 & 0.0115 & -0.0310 & 0.0177 \\
\hline & $(0.0356)$ & $(0.0456)$ & $(0.0374)$ & $(0.0505)$ \\
\hline \multirow[t]{2}{*}{ Old-age-dependency ratio } & -0.0110 & 0.00788 & -0.0298 & 0.00824 \\
\hline & $(0.0255)$ & $(0.0353)$ & $(0.0202)$ & $(0.0472)$ \\
\hline \multirow[t]{2}{*}{ Private final consumption expenditure growth rate } & -0.101 & -0.347 & -0.0233 & -0.284 \\
\hline & $(0.124)$ & $(0.247)$ & $(0.159)$ & $(0.231)$ \\
\hline \multirow[t]{2}{*}{ Initial other social exp., in \% of GDP } & -0.0335 & 0.0102 & -0.0334 & -0.00761 \\
\hline & $(0.0315)$ & $(0.0705)$ & $(0.0318)$ & $(0.0424)$ \\
\hline \multirow[t]{2}{*}{ Trade openness } & -0.00110 & 0.00272 & -0.00162 & 0.00314 \\
\hline & $(0.00207)$ & $(0.00283)$ & $(0.00173)$ & $(0.00266)$ \\
\hline \multirow[t]{2}{*}{ Government balance } & 0.00282 & 0.00965 & -0.00285 & $6.81 \mathrm{e}-06$ \\
\hline & $(0.0246)$ & $(0.0332)$ & $(0.0212)$ & $(0.0330)$ \\
\hline \multirow[t]{2}{*}{ SD government expenditures } & $0.321^{\star \star *}$ & -0.0205 & $0.261^{\star \star *}$ & -0.0186 \\
\hline & $(0.0612)$ & $(0.0665)$ & $(0.0486)$ & $(0.0997)$ \\
\hline \multirow[t]{2}{*}{ Banking crisis } & -0.145 & -0.187 & 0.0222 & -0.0897 \\
\hline & $(0.141)$ & $(0.354)$ & $(0.147)$ & $(0.376)$ \\
\hline \multirow[t]{2}{*}{ Political stability } & $-0.0744^{*}$ & $-0.122^{* *}$ & $-0.0707^{\star * *}$ & $-0.122^{\star * *}$ \\
\hline & $(0.0423)$ & $(0.0546)$ & $(0.0167)$ & $(0.0411)$ \\
\hline Observations & 210 & 210 & 192 & 192 \\
\hline Number of countries & 35 & 35 & 35 & 35 \\
\hline Country-FE & $\mathrm{Y}$ & $\mathrm{Y}$ & $\mathrm{Y}$ & $\mathrm{Y}$ \\
\hline Year-FE & $\mathrm{N}$ & Y & $\mathrm{N}$ & $\mathrm{Y}$ \\
\hline Hansen test ( $p$-value) & 0.519 & 0.673 & 0.891 & 0.947 \\
\hline A-B AR(2) test ( $p$-value) & 0.655 & 0.897 & 0.678 & 0.624 \\
\hline
\end{tabular}

Note: Standard errors in parentheses are computed following Windmeijer (2004); A-B AR(2) - Arellano-Bond test for serial correlation of second order; ${ }^{* * *} p<0.01,{ }^{* *} p<0.05,{ }^{*} p<0.1$.

Source: OECD, IMF WEO, Polity IV Project. 
Table 14 / Pension Funds' Assets - Gross Fixed Capital Formation Growth Rate Volatility

\begin{tabular}{|c|c|c|c|c|}
\hline \multirow[t]{3}{*}{ Dependent variable: } & \multicolumn{4}{|c|}{ SD gross fixed capital formation growth rate, log } \\
\hline & \multicolumn{2}{|c|}{ Least Squares Fixed Effects } & \multicolumn{2}{|c|}{ Bias-Corrected LSDV } \\
\hline & $(1)$ & $(2)$ & $(3)$ & $(4)$ \\
\hline \multirow[t]{2}{*}{ Lagged dependent variable } & - & - & 0.0992 & -0.0242 \\
\hline & $(-)$ & $(-)$ & $(0.140)$ & $(0.149)$ \\
\hline \multirow[t]{2}{*}{ Initial real GDP p.c. level, log } & 0.239 & 1.01 & 0.37 & 0.986 \\
\hline & $(0.874)$ & $(1.485)$ & $(0.779)$ & $(1.092)$ \\
\hline \multirow[t]{2}{*}{ Initial public pension exp., in \% of GDP } & -0.096 & -0.0112 & -0.0833 & -0.00102 \\
\hline & $(0.091)$ & $(0.138)$ & $(0.110)$ & $(0.130)$ \\
\hline \multirow[t]{2}{*}{ Old-age-dependency ratio } & 0.0081 & 0.021 & 0.00118 & 0.0193 \\
\hline & $(0.023)$ & $(0.034)$ & $(0.034)$ & $(0.037)$ \\
\hline \multirow[t]{2}{*}{ Gross fixed capital formation growth rate } & $0.200^{*}$ & 0.192 & $0.208^{* * *}$ & $0.194^{* * *}$ \\
\hline & $(0.120)$ & $(0.127)$ & $(0.063)$ & $(0.064)$ \\
\hline \multirow[t]{2}{*}{ Initial other social exp., in \% of GDP } & $-0.111^{*}$ & -0.112 & $-0.122^{*}$ & $-0.122^{*}$ \\
\hline & $(0.067)$ & $(0.074)$ & $(0.065)$ & $(0.065)$ \\
\hline \multirow[t]{2}{*}{ Trade openness } & -0.00143 & 0.000182 & -0.00251 & 0.000675 \\
\hline & $(0.006)$ & $(0.007)$ & $(0.006)$ & $(0.006)$ \\
\hline \multirow[t]{2}{*}{ Government balance } & -0.0524 & -0.062 & -0.0549 & -0.0659 \\
\hline & $(0.062)$ & $(0.067)$ & $(0.042)$ & $(0.047)$ \\
\hline \multirow[t]{2}{*}{ SD government expenditures } & $0.256^{\star * *}$ & $0.184^{* *}$ & $0.259^{* * *}$ & 0.179 \\
\hline & $(0.077)$ & $(0.090)$ & $(0.097)$ & $(0.115)$ \\
\hline \multirow[t]{2}{*}{ Banking crisis } & 0.443 & 0.38 & 0.461 & 0.407 \\
\hline & $(0.315)$ & $(0.646)$ & $(0.300)$ & $(0.406)$ \\
\hline \multirow[t]{2}{*}{ Political stability } & -0.00348 & -0.00634 & -0.00459 & 0.000604 \\
\hline & $(0.759)$ & $(1.792)$ & $(0.053)$ & $(0.053)$ \\
\hline \multirow[t]{2}{*}{ Pension funds' assets, in \% of GDP } & -0.00544 & -0.00328 & -0.00621 & -0.00251 \\
\hline & $(0.008)$ & $(0.009)$ & $(0.006)$ & $(0.006)$ \\
\hline Observations & 97 & 97 & 97 & 97 \\
\hline Number of countries & 32 & 32 & 32 & 32 \\
\hline Country-FE & $\mathrm{Y}$ & $\mathrm{Y}$ & $\mathrm{Y}$ & $\mathrm{Y}$ \\
\hline Year-FE & $\mathrm{N}$ & $\mathrm{Y}$ & $\mathrm{N}$ & $\mathrm{Y}$ \\
\hline
\end{tabular}

Note: Bootstrapped standard errors in parentheses are computed following Windmeijer (2004);

${ }^{* * *} p<0.01,{ }^{* *} p<0.05,{ }^{*} p<0.1$.

Source: OECD, IMF WEO, Polity IV Project. 
Wiiw Working Paper 172

Table 15 / Pension Funds' Assets - Private Final Consumption Expenditure Growth Rate Volatility

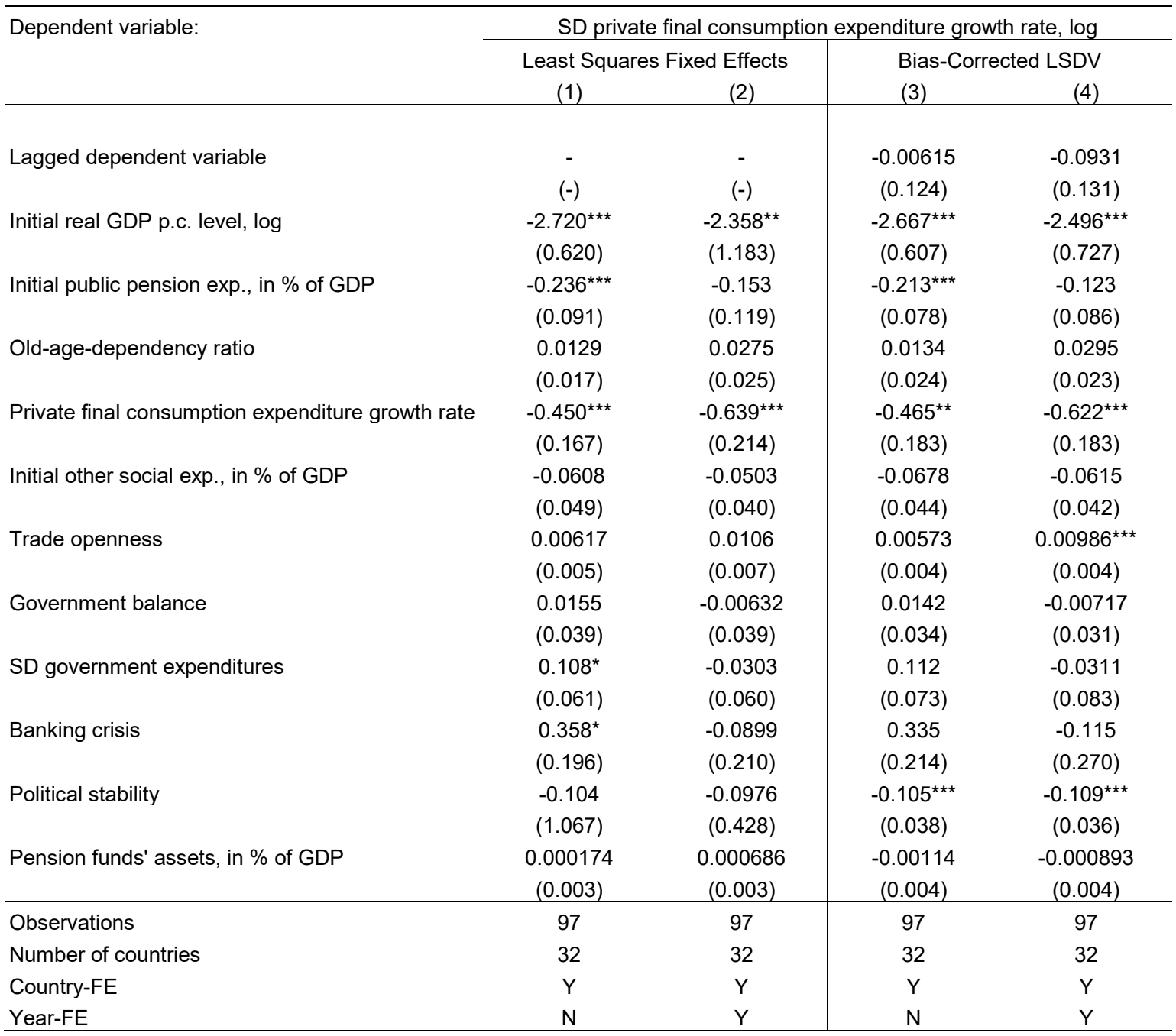

Note: Bootstrapped standard errors in parentheses are computed following Windmeijer (2004);

${ }^{\star * *} p<0.01,{ }^{* *} p<0.05,{ }^{*} p<0.1$.

Source: OECD, IMF WEO, Polity IV Project. 
Table 16 / GMM Regressions - Pension Funds' Assets - Gross Fixed Capital Formation Growth Rate Volatility

\section{System GMM Two-Step}

Dependent variable:

SD gross fixed capital formation growth rate, log

\begin{tabular}{|c|c|c|c|c|}
\hline & $(1)$ & $(2)$ & (3) & $(4)$ \\
\hline \multirow[t]{2}{*}{ Lagged dependent variable } & - & - & 0.0567 & -0.141 \\
\hline & $(-)$ & $(-)$ & $(0.211)$ & $(0.354)$ \\
\hline \multirow[t]{2}{*}{ Initial real GDP p.c. level, log } & 0.118 & -0.139 & 0.0960 & -0.657 \\
\hline & $(0.160)$ & $(0.708)$ & $(0.157)$ & (1.253) \\
\hline \multirow[t]{2}{*}{ Initial public pension exp., in \% of GDP } & 0.131 & 0.00487 & 0.106 & 0.101 \\
\hline & $(0.140)$ & $(0.133)$ & $(0.162)$ & $(0.158)$ \\
\hline \multirow[t]{2}{*}{ Old-age-dependency ratio } & -0.0135 & 0.0300 & -0.00350 & 0.0297 \\
\hline & $(0.0359)$ & $(0.0311)$ & $(0.0372)$ & $(0.0862)$ \\
\hline \multirow[t]{2}{*}{ Gross fixed capital formation growth rate } & 0.0999 & 0.0334 & 0.108 & 0.0241 \\
\hline & $(0.147)$ & $(0.171)$ & $(0.124)$ & $(0.291)$ \\
\hline \multirow[t]{2}{*}{ Initial other social exp., in \% of GDP } & -0.100 & -0.0423 & $-0.116^{*}$ & -0.100 \\
\hline & $(0.0624)$ & $(0.104)$ & $(0.0616)$ & $(0.112)$ \\
\hline \multirow[t]{2}{*}{ Trade openness } & $0.00717^{\star \star}$ & 0.00529 & $0.00720^{\star * *}$ & 0.0113 \\
\hline & $(0.00294)$ & $(0.00359)$ & $(0.00270)$ & $(0.00805)$ \\
\hline \multirow[t]{2}{*}{ Government balance } & -0.0426 & -0.0345 & -0.0613 & -0.0765 \\
\hline & $(0.0633)$ & $(0.0541)$ & $(0.0488)$ & $(0.0828)$ \\
\hline \multirow[t]{2}{*}{ SD government expenditures } & $0.424^{* \star *}$ & 0.0233 & $0.413^{* * *}$ & 0.121 \\
\hline & $(0.147)$ & $(0.160)$ & $(0.144)$ & $(0.373)$ \\
\hline \multirow[t]{2}{*}{ Banking crisis } & -0.229 & -0.119 & -0.107 & 0.0486 \\
\hline & $(0.441)$ & $(0.678)$ & $(0.421)$ & $(0.844)$ \\
\hline \multirow[t]{2}{*}{ Political stability } & -0.00119 & -0.0173 & -0.0147 & -0.0177 \\
\hline & $(0.0361)$ & $(0.0482)$ & $(0.0381)$ & $(0.123)$ \\
\hline \multirow[t]{2}{*}{ Pension funds' assets, in \% of GDP } & 0.00513 & -0.00371 & 0.00571 & 0.00822 \\
\hline & $(0.00497)$ & $(0.00573)$ & $(0.00617)$ & $(0.00893)$ \\
\hline Observations & 97 & 97 & 97 & 97 \\
\hline Number of countries & 32 & 32 & 32 & 32 \\
\hline Country-FE & $\mathrm{Y}$ & $\mathrm{Y}$ & $\mathrm{Y}$ & $\mathrm{Y}$ \\
\hline Year-FE & $\mathrm{N}$ & $\mathrm{Y}$ & $N$ & $\mathrm{Y}$ \\
\hline Hansen test (p-value) & 0.701 & 0.704 & 0.907 & 0.740 \\
\hline A-B AR(2) test ( $p$-value) & 0.318 & 0.325 & 0.315 & 0.296 \\
\hline
\end{tabular}

Note: Standard errors in parentheses are computed following Windmeijer (2004); A-B AR(2) - Arellano-Bond test for serial correlation of second order; ${ }^{* * *} p<0.01,{ }^{* *} p<0.05,{ }^{*} p<0.1$.

Source: OECD, IMF WEO, Polity IV Project. 
WiilW Working Paper 172

Table 17 / GMM Regressions - Pension Funds' Assets - Private Final Consumption Expenditure Growth Rate Volatility

System GMM Two-Step

Dependent variable: SD private final consumption expenditure growth rate, log (1)

(3)

Lagged dependent variable

\section{$(-)$}

Initial real GDP p.c. level, log

Initial public pension exp., in \% of GDP

Old-age-dependency ratio

Private final consumption expenditure growth rate

Initial other social exp., in \% of GDP

Trade openness

Government balance

SD government expenditures

Banking crisis

Political stability

Pension funds' assets, in \% of GDP

Observations

Number of countries

Country-FE

Year-FE

Hansen test ( $p$-value)

A-B AR(2) test ( $p$-value)

\subsection{8}

$(0.167)$

$-0.0650^{*}$

(0.0385)

0.0192

(0.0309)

$-0.303$

$(0.302)$

$-0.0466$

$(0.0485)$

0.000818

$(0.00226)$

$-0.0152$

(0.0510)

$0.286^{\star \star *}$

(0.0553)

0.0349

(0.288)

$-0.0774^{* * *}$

(0.0269)

$-0.00122$

$(0.00250)$
$(-)$

$-0.581$

$(0.457)$

$-0.0723$

(0.0525)

$0.0664^{* * *}$

(0.0190)

$-0.389^{* *}$

$(0.171)$

$-0.0418$

(0.0305)

$0.00302^{*}$

(0.00176)

$-0.0112$

(0.0414)

$-0.0247$

$(0.102)$

0.109

(0.349)

$-0.106^{* * *}$

(0.0200)

$-0.00115$

(0.00410)

0.113

$-0.107$

(0.175)

(0.248)

0.131

$-0.765$

(0.143)

(0.497)

$-0.0864^{* *}$

$-0.0478$

(0.0356)

(0.0532)

0.00805

$0.0562^{* * *}$

(0.0280)

(0.0204)

$-0.314$

$-0.673^{\star *}$

(0.314)

(0.326)

$-0.0487$

0.0179

(0.0399)

(0.0435)

$-0.000866$

$0.00455^{\star \star}$

(0.00186)

$(0.00187)$

$-0.00770$

$-0.00441$

(0.0465)

(0.0403)

$0.245^{* * *} \quad-0.211^{* *}$

(0.0873)

$(0.107)$

$0.173 \quad-0.0826$

(0.276)

(0.320)

$-0.0760^{* * *}$

$-0.131^{\star \star *}$

(0.0195)

(0.0345)

$-0.00215$

$-0.00230$

$(0.00218)$

$(0.00281)$

$\begin{array}{cccc}97 & 97 & 97 & 97 \\ 32 & 32 & 32 & 32 \\ \mathrm{Y} & \mathrm{Y} & \mathrm{Y} & \mathrm{Y} \\ \mathrm{N} & \mathrm{Y} & \mathrm{N} & \mathrm{Y} \\ 0.936 & 0.966 & 0.976 & 0.999 \\ 0.117 & 0.759 & 0.133 & 0.387\end{array}$

Note: Standard errors in parentheses are computed following Windmeijer (2004); A-B AR(2) - Arellano-Bond test for serial correlation of second order; ${ }^{* * *} p<0.01,{ }^{* *} p<0.05,{ }^{*} p<0.1$.

Source: OECD, IMF WEO, Polity IV Project. 
Table 18 / Pension Funds' Benefits- Gross Fixed Capital Formation Growth Rate Volatility

\begin{tabular}{|c|c|c|c|c|}
\hline \multirow[t]{3}{*}{ Dependent variable: } & \multicolumn{4}{|c|}{ SD gross fixed capital formation growth rate, log } \\
\hline & \multicolumn{2}{|c|}{ Least Squares Fixed Effects } & \multicolumn{2}{|c|}{ Bias-Corrected LSDV } \\
\hline & $(1)$ & $(2)$ & (3) & $(4)$ \\
\hline \multirow[t]{2}{*}{ Lagged dependent variable } & - & - & -0.134 & $-0.243^{*}$ \\
\hline & $(-)$ & $(-)$ & $(0.152)$ & $(0.148)$ \\
\hline \multirow[t]{2}{*}{ Initial real GDP p.c. level, log } & -0.109 & 1.217 & -0.370 & 0.861 \\
\hline & $(0.968)$ & $(1.945)$ & $(0.702)$ & $(1.118)$ \\
\hline \multirow[t]{2}{*}{ Initial public pension exp., in \% of GDP } & -0.0849 & 0.0652 & -0.0577 & 0.110 \\
\hline & $(0.0945)$ & $(0.212)$ & $(0.122)$ & $(0.151)$ \\
\hline \multirow[t]{2}{*}{ Old-age-dependency ratio } & -0.00653 & 0.00806 & -0.00219 & 0.0153 \\
\hline & $(0.0278)$ & $(0.0394)$ & $(0.0327)$ & $(0.0330)$ \\
\hline \multirow[t]{2}{*}{ Gross fixed capital formation growth rate } & 0.165 & 0.140 & $0.158^{* *}$ & $0.121^{*}$ \\
\hline & $(0.162)$ & $(0.157)$ & $(0.0725)$ & $(0.0724)$ \\
\hline \multirow[t]{2}{*}{ Initial other social exp., in \% of GDP } & -0.0683 & -0.110 & -0.0813 & -0.143 \\
\hline & $(0.0737)$ & $(0.0856)$ & $(0.0771)$ & $(0.0887)$ \\
\hline \multirow[t]{2}{*}{ Trade openness } & 0.00454 & 0.00400 & 0.00591 & 0.00576 \\
\hline & $(0.00810)$ & $(0.00861)$ & $(0.00646)$ & $(0.00651)$ \\
\hline \multirow[t]{2}{*}{ Government balance } & -0.0320 & -0.0387 & -0.0390 & -0.0473 \\
\hline & $(0.0768)$ & $(0.0791)$ & $(0.0571)$ & $(0.0660)$ \\
\hline \multirow[t]{2}{*}{ SD government expenditures } & $0.331^{* * *}$ & 0.187 & $0.313^{* * *}$ & 0.156 \\
\hline & $(0.0997)$ & $(0.142)$ & $(0.0972)$ & $(0.115)$ \\
\hline \multirow[t]{2}{*}{ Banking crisis } & -0.0256 & 0.0855 & -0.0415 & 0.101 \\
\hline & $(0.267)$ & $(0.316)$ & $(0.252)$ & $(0.260)$ \\
\hline \multirow[t]{2}{*}{ Political stability } & -0.139 & -0.141 & -0.157 & -0.180 \\
\hline & $(0.650)$ & $(0.734)$ & $(0.264)$ & $(0.256)$ \\
\hline \multirow[t]{2}{*}{ Pension funds' benefits, in $\%$ of GDP } & $0.206^{\star *}$ & $0.239^{\star \star \star}$ & $0.235^{\star \star}$ & $0.293^{\star * *}$ \\
\hline & $(0.0953)$ & $(0.0891)$ & $(0.114)$ & $(0.111)$ \\
\hline Observations & 79 & 79 & 79 & 79 \\
\hline Number of countries & 26 & 26 & 26 & 26 \\
\hline Country-FE & $\mathrm{Y}$ & $\mathrm{Y}$ & $\mathrm{Y}$ & $\mathrm{Y}$ \\
\hline Year-FE & $\mathrm{N}$ & $\mathrm{Y}$ & $\mathrm{N}$ & $\mathrm{Y}$ \\
\hline
\end{tabular}

Note: Bootstrapped standard errors in parentheses are computed following Windmeijer (2004);

*** $\mathrm{p}<0.01,{ }^{* *} \mathrm{p}<0.05,{ }^{*} \mathrm{p}<0.1$.

Source: OECD, IMF WEO, Polity IV Project. 
Wiiw Working Paper 172

Table 19 / Pension Funds' Benefits - Private Final Consumption Expenditure Growth Rate Volatility

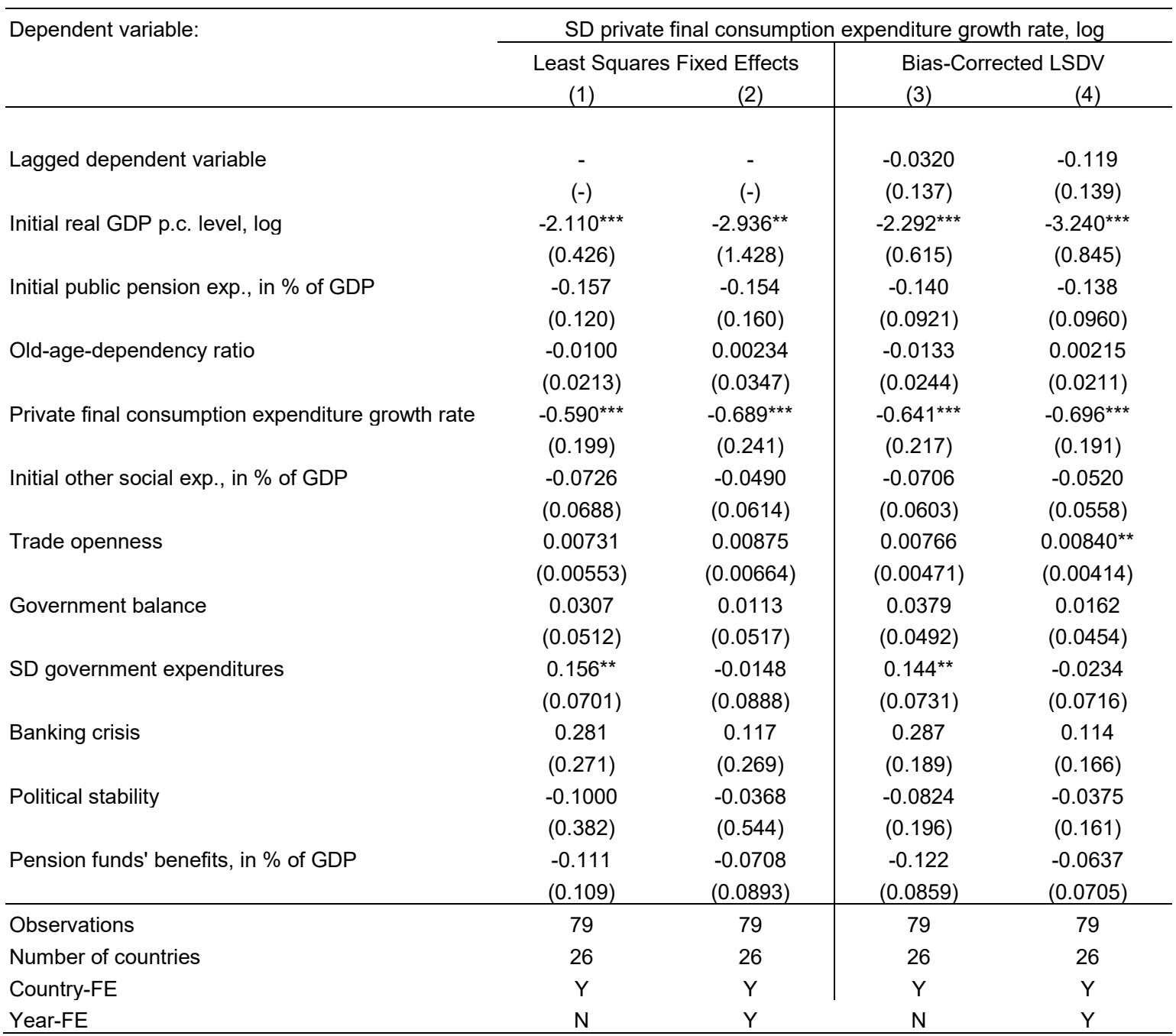

Note: Bootstrapped standard errors in parentheses are computed following Windmeijer (2004);

${ }^{* * *} p<0.01,{ }^{* *} p<0.05,{ }^{*} p<0.1$.

Source: OECD, IMF WEO, Polity IV Project. 
Table 20 / GMM Regressions - Pension Funds' Benefits - Gross Fixed Capital Formation Growth Rate Volatility

\begin{tabular}{|c|c|c|c|c|}
\hline \multirow[t]{2}{*}{ Dependent variable: } & \multicolumn{4}{|c|}{$\begin{array}{c}\text { System GMM Two-Step } \\
\text { SD gross fixed capital formation growth rate, log }\end{array}$} \\
\hline & $(1)$ & (2) & (3) & $(4)$ \\
\hline \multirow[t]{2}{*}{ Lagged dependent variable } & & & 0.240 & -0.357 \\
\hline & & & $(0.223)$ & $(0.553)$ \\
\hline \multirow[t]{2}{*}{ Initial real GDP p.c. level, log } & -0.0266 & 1.243 & -0.0541 & 0.620 \\
\hline & $(0.388)$ & $(1.269)$ & $(0.352)$ & $(1.211)$ \\
\hline \multirow[t]{2}{*}{ Initial public pension exp., in $\%$ of GDP } & -0.113 & 0.0869 & -0.0814 & 0.0610 \\
\hline & $(0.137)$ & $(0.0934)$ & $(0.143)$ & $(0.140)$ \\
\hline \multirow[t]{2}{*}{ Old-age-dependency ratio } & 0.0209 & 0.0187 & 0.00668 & 0.0576 \\
\hline & $(0.0346)$ & $(0.0653)$ & $(0.0467)$ & $(0.0647)$ \\
\hline \multirow[t]{2}{*}{ Gross fixed capital formation growth rate } & 0.204 & 0.124 & 0.129 & 0.158 \\
\hline & $(0.230)$ & $(0.206)$ & $(0.246)$ & $(0.216)$ \\
\hline \multirow[t]{2}{*}{ Initial other social exp., in \% of GDP } & 0.0177 & -0.141 & -0.0225 & -0.223 \\
\hline & $(0.0728)$ & $(0.164)$ & $(0.140)$ & $(0.181)$ \\
\hline \multirow[t]{2}{*}{ Trade openness } & 0.000394 & 0.00332 & 0.00109 & 0.00629 \\
\hline & $(0.00254)$ & $(0.00601)$ & $(0.00248)$ & $(0.00965)$ \\
\hline \multirow[t]{2}{*}{ Government balance } & 0.000837 & 0.00436 & 0.0132 & -0.0256 \\
\hline & $(0.0964)$ & $(0.111)$ & $(0.110)$ & $(0.102)$ \\
\hline \multirow[t]{2}{*}{ SD government expenditures } & $0.230^{\star *}$ & 0.134 & $0.229^{* * *}$ & 0.0775 \\
\hline & $(0.0983)$ & $(0.213)$ & $(0.0801)$ & $(0.233)$ \\
\hline \multirow[t]{2}{*}{ Banking crisis } & 0.391 & 0.127 & 0.366 & 0.436 \\
\hline & $(0.513)$ & $(0.406)$ & $(0.509)$ & $(0.676)$ \\
\hline \multirow[t]{2}{*}{ Political stability } & 0.0660 & -0.550 & 0.153 & -0.249 \\
\hline & $(0.294)$ & $(0.586)$ & $(0.408)$ & $(0.928)$ \\
\hline \multirow[t]{2}{*}{ Pension funds' benefits, in $\%$ of GDP } & -0.0873 & 0.0904 & 0.0137 & 0.144 \\
\hline & $(0.116)$ & $(0.184)$ & $(0.176)$ & $(0.223)$ \\
\hline Observations & 79 & 79 & 79 & 79 \\
\hline Number of countries & 26 & 26 & 26 & 26 \\
\hline Country-FE & $\mathrm{Y}$ & $\mathrm{Y}$ & $\mathrm{Y}$ & $\mathrm{Y}$ \\
\hline Year-FE & $\mathrm{N}$ & $\mathrm{Y}$ & $\mathrm{N}$ & $\mathrm{Y}$ \\
\hline Hansen test ( $p$-value) & 0.998 & 1.000 & 1.000 & 1.000 \\
\hline A-B AR(2) test ( $p$-value) & 0.820 & 0.361 & 0.651 & 0.667 \\
\hline
\end{tabular}


Wiiw Working Paper 172

Table 21 / GMM Regressions - Pension Funds' Benefits- Private Final Consumption Expenditure Growth Rate Volatility

System GMM Two-Step

Dependent variable: SD private final consumption expenditure growth rate, log (1)

(3)

Lagged dependent variable

Initial real GDP p.c. level, log

Initial public pension exp., in \% of GDP

Old-age-dependency ratio

Private final consumption expenditure growth rate

Initial other social exp., in \% of GDP

Trade openness

Government balance

SD government expenditures

Banking crisis

Political stability

Pension funds' benefits, in $\%$ of GDP

Observations

Number of countries

Country-FE

Year-FE

Hansen test ( $p$-value)

A-B AR(2) test (p-value)

\section{$(-)$}

$-0.0376$

(0.281)

$-0.0955^{*}$

(0.0550)

0.0150

(0.0288)

0.0378

$(0.266)$

$-0.0457$

(0.0504)

$-0.000797$

(0.00324)

$-0.00445$

(0.0469)

$0.302^{* * *}$

(0.0820)

0.355

(0.479)

0.0339

(0.278)

$-0.0455$

(0.116)

79

26

$Y$

$\mathrm{N}$

0.988

0.254
(2)

-

$(-)$

$-1.163$

(0.941)

$-0.0638$

(0.0434)

0.00300

(0.0351)

$-0.199$

(0.322)

0.0544

(0.101)

$-0.000601$

(0.00264)

0.0516

(0.0710)

0.0291

(0.0988)

0.143

$(0.282)$

0.00580

(0.245)

$-0.0757$

(0.0894)

79

26

Y

Y

0.993

0.339
0.298

$(0.224) \quad(0.362)$

0.0114

$-0.823$

(0.291)

$(0.731)$

$-0.103^{*}$

$-0.0319$

(0.0550)

(0.0888)

0.00785

$-0.0130$

(0.0276)

$(0.0451)$

$-0.0508$

$-0.242$

(0.340)

(0.338)

0.0221

(0.0453)

0.0656

(0.0591)

$-0.00241$

$-0.000688$

$(0.00401)$

$(0.00251)$

0.00490

0.0650

(0.0621)

(0.0556)

0.00720

$(0.0787) \quad(0.162)$

$0.252 \quad-0.0265$

\begin{tabular}{ll}
$(0.604) \quad(0.465)$ \\
\hline
\end{tabular}

$\begin{array}{ll}-0.0276 & 0.0562\end{array}$

$(0.304) \quad(0.338)$

$\begin{array}{ll}-0.147 & -0.0281\end{array}$

(0.122)

(0.148)

\begin{tabular}{cc}
79 & 79 \\
26 & 26 \\
$\mathrm{Y}$ & $\mathrm{Y}$ \\
$\mathrm{N}$ & $\mathrm{Y}$ \\
0.998 & 0.999 \\
0.398 & 0.152 \\
\hline
\end{tabular}

Note: Standard errors in parentheses are computed following Windmeijer (2004); A-B AR(2) - Arellano-Bond test for serial correlation of second order; ${ }^{* * *} p<0.01,{ }^{* *} p<0.05,{ }^{*} p<0.1$.

Source: OECD, IMF WEO, Polity IV Project. 
IMPRESSUM

Herausgeber, Verleger, Eigentümer und Hersteller:

Verein "Wiener Institut für Internationale Wirtschaftsvergleiche“ (wiiw),

Wien 6, Rahlgasse 3

ZVR-Zahl: 329995655

Postanschrift: A 1060 Wien, Rahlgasse 3, Tel: [+431] 53366 10, Telefax: [+431] 533661050 Internet Homepage: www.wiiw.ac.at

Nachdruck nur auszugsweise und mit genauer Quellenangabe gestattet.

Offenlegung nach $\S 25$ Mediengesetz: Medieninhaber (Verleger): Verein "Wiener Institut für Internationale Wirtschaftsvergleiche", A 1060 Wien, Rahlgasse 3. Vereinszweck: Analyse der wirtschaftlichen Entwicklung der zentral- und osteuropäischen Länder sowie anderer Transformationswirtschaften sowohl mittels empirischer als auch theoretischer Studien und ihre Veröffentlichung; Erbringung von Beratungsleistungen für Regierungs- und Verwaltungsstellen, Firmen und Institutionen. 


\section{wiiw}
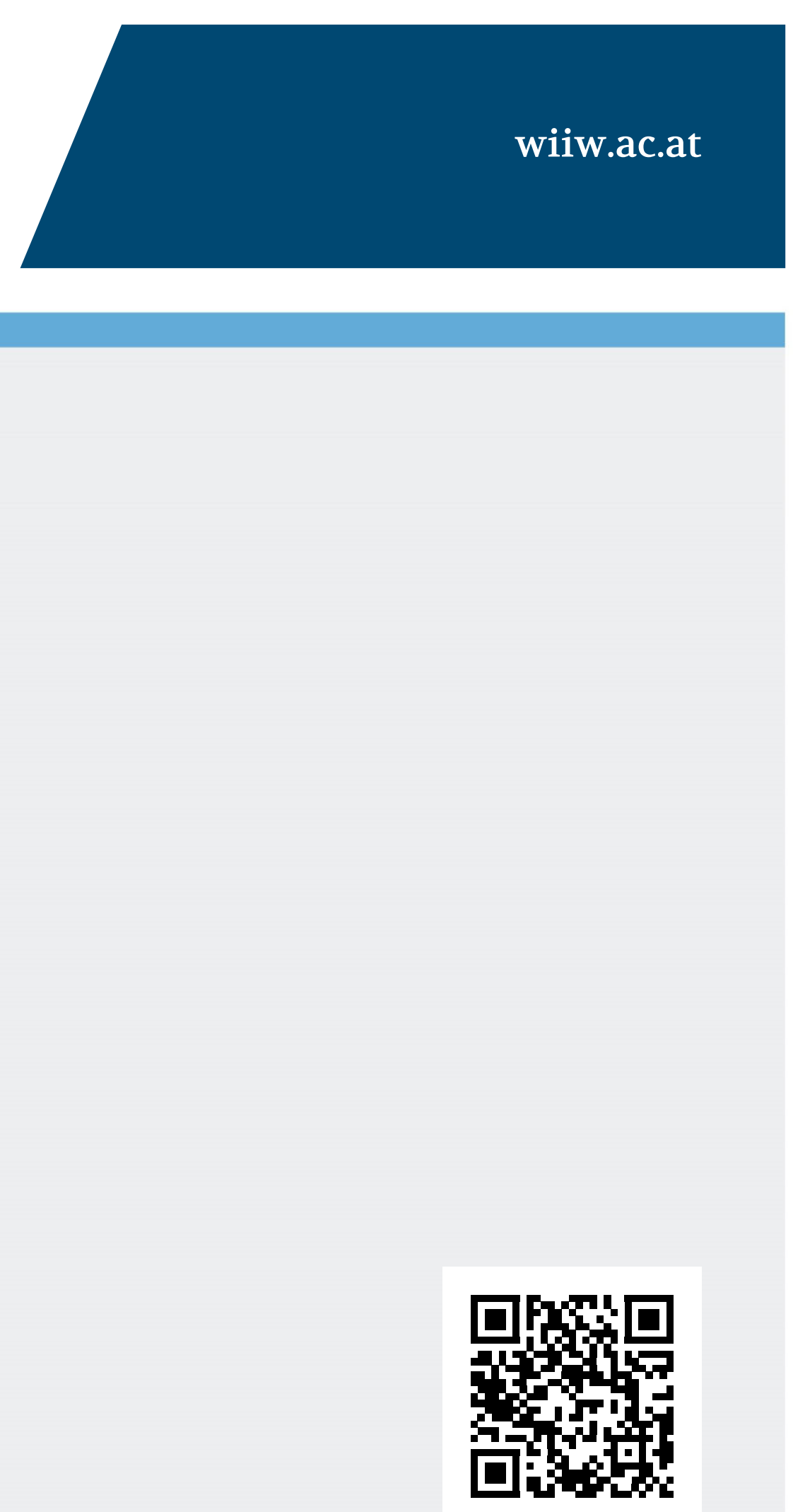

https://wiiw.ac.at/p-5159.html 